Prepared in cooperation with the

U.S. Environmental Protection Agency as part of the Great Lakes Restoration Initiative

\title{
Streamflow and Estimated Loads of Phosphorus and Dissolved and Suspended Solids From Selected Tributaries to Lake Ontario, New York, Water Years 2012-14
}

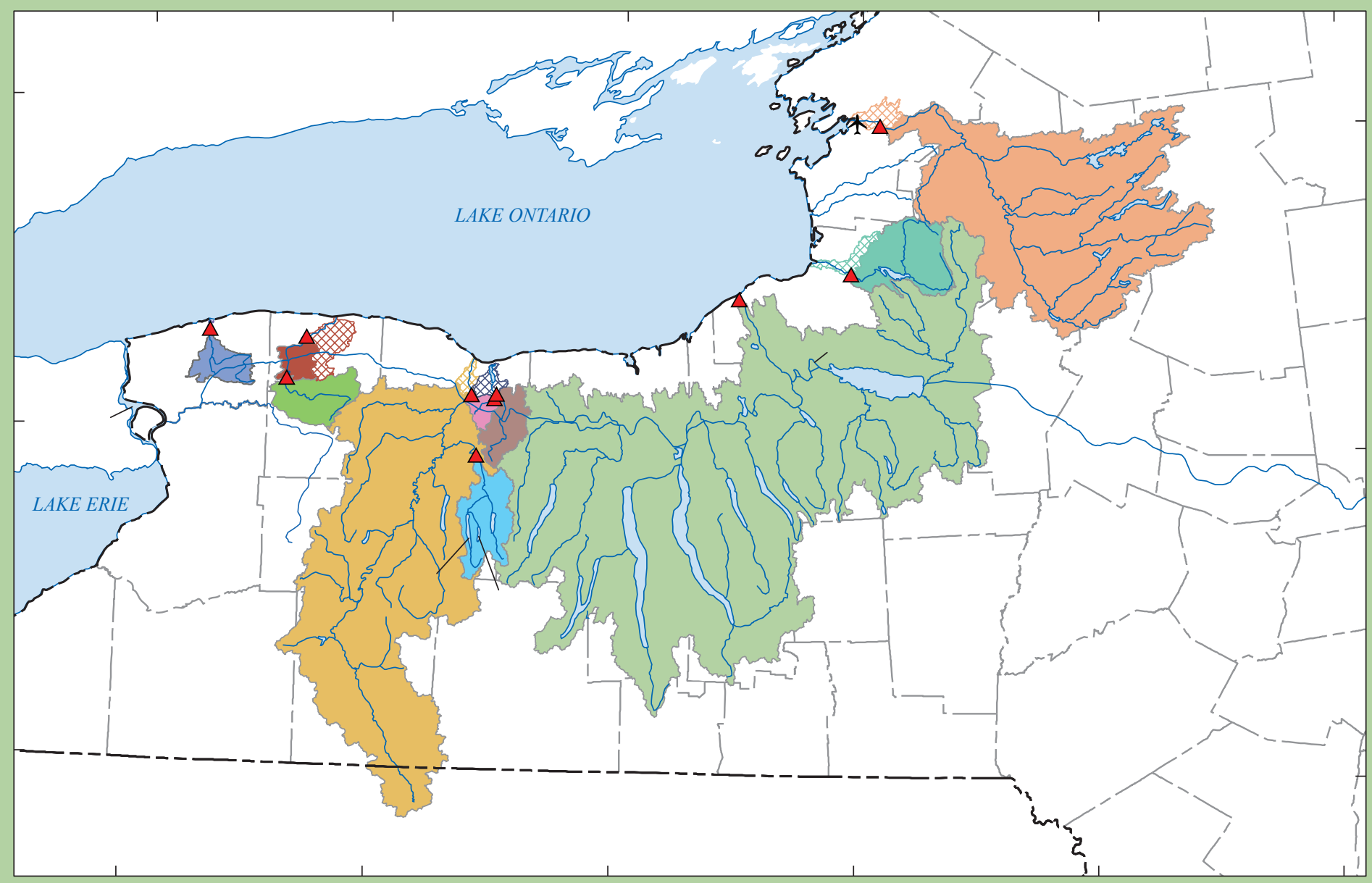

Scientific Investigations Report 2016-5084 
Cover. Sampling on the lower Genesee River in 2013, downstream of the Genesee River at the Ford Street monitoring station. Photograph by Henry Zajd, Jr., U.S. Geological Survey. 


\section{Streamflow and Estimated Loads of Phosphorus and Dissolved and Suspended Solids From Selected Tributaries to Lake Ontario, New York, Water Years 2012-14}

By Brett A. Hayhurst, Benjamin N. Fisher, and James E. Reddy

Prepared in cooperation with the

U.S. Environmental Protection Agency as part of the

Great Lakes Restoration Initiative

Scientific Investigations Report 2016-5084 


\title{
U.S. Department of the Interior SALLY JEWELL, Secretary
}

\section{U.S. Geological Survey Suzette M. Kimball, Director}

\author{
U.S. Geological Survey, Reston, Virginia: 2016
}

For more information on the USGS - the Federal source for science about the Earth, its natural and living resources, natural hazards, and the environment-visit http://www.usgs.gov or call 1-888-ASK-USGS.

For an overview of USGS information products, including maps, imagery, and publications, visit http://store.usgs.gov.

Any use of trade, firm, or product names is for descriptive purposes only and does not imply endorsement by the U.S. Government.

Although this information product, for the most part, is in the public domain, it also may contain copyrighted materials as noted in the text. Permission to reproduce copyrighted items must be secured from the copyright owner.

Suggested citation:

Hayhurst, B.A., Fisher, B.N., and Reddy, J.E., 2016, Streamflow and estimated loads of phosphorus and dissolved and suspended solids from selected tributaries to Lake Ontario, New York, water years 2012-14: U.S. Geological Survey Scientific Investigations Report 2016-5084, 34 p., http://dx.doi.org/10.3133/sir20165084.

ISSN 2328-0328 (online) 


\section{Acknowledgments}

Special thanks are extended to the personnel of Monroe County Department of Environmental Services and New York Department of Environmental Conservation for assistance in site selection and field support. Special thanks also are extended to the hydrologic technicians Albert Morgan and John Wernly of the U.S. Geological Survey for surface-water and water-quality data collection at the Lake Ontario tributary sites. 



\section{Contents}

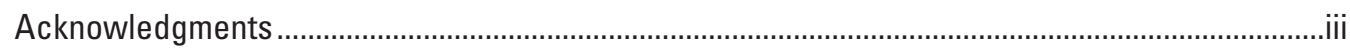

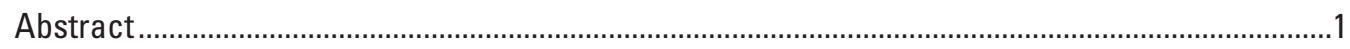

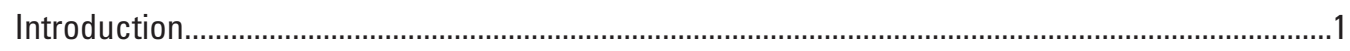

Study Area

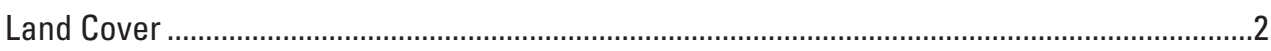

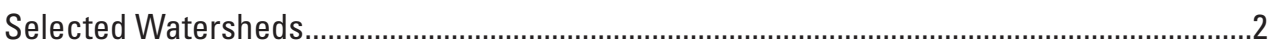

Tributaries to Lake Ontario ......................................................................................

Influences of New York State Barge Canal .....................................................................

Climate

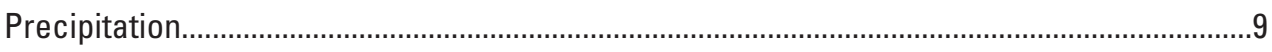

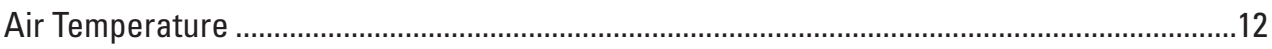

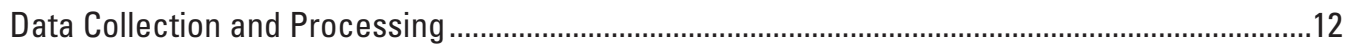

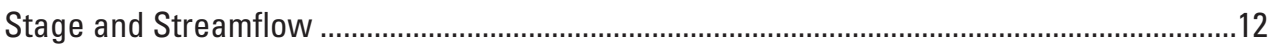

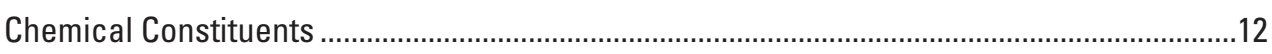

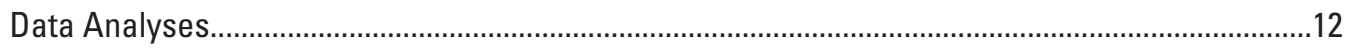

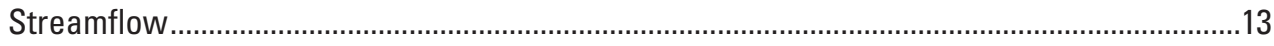

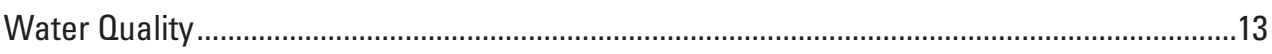

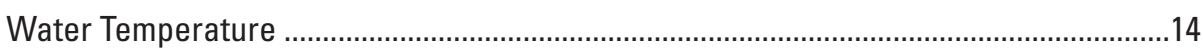

Specific Conductance.............................................................................................. 14

Nutrients, Total Suspended Solids, and Total Dissolved Solids ........................................14

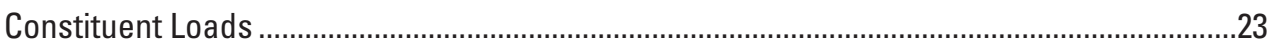

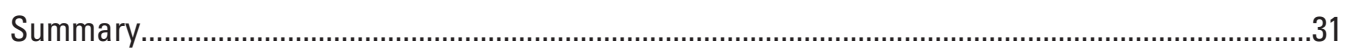

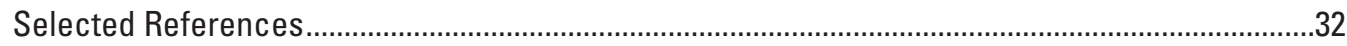

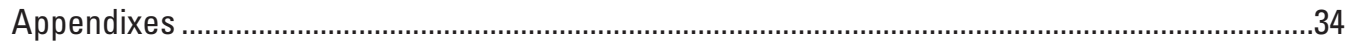

\section{Figures}

1. Map showing location of monitoring sites on tributaries to Lake Ontario, New York.......3

2. Map showing land cover classifications of selected basins in the Lake Ontario watershed, New York ..................................................................................................

3. Map showing generalized bedrock geology of selected basins in the Lake Ontario watershed, New York. Geology is modified from Cadwell (1999) .....................................7

4. Map showing generalized surficial geology of selected basins in the Lake Ontario watershed, New York. Geology modified from Fisher and others (1970)..........................8

5. Graphs showing precipitation and temperature at selected airports in New York.........10

6. Graph showing monthly mean streamflow for selected tributaries to Lake Ontario, New York, water years 2012-14 ................................................................................13

7. Graph showing annual mean streamflow yields for selected tributaries to Lake Ontario, New York, water years 2012-14..............................................................14

8. Map showing mean annual streamflow yields for selected tributaries to Lake Ontario, New York, water years 2012-14 ..........................................................15

9. Map showing median specific conductance at sites on selected tributaries to Lake Ontario, New York, water years 2012-14................................................................18 
10. Map showing median suspended solids concentrations at sites on selected tributaries to Lake Ontario, New York, water years 2012-14...

11. Map showing median phosphorus concentrations at sites on selected tributaries to Lake Ontario, New York, water years 2012-14.

12. Map showing median orthophosphate concentrations at sites on selected tributaries to Lake Ontario, New York, water years 2012-14.

13. Map showing median dissolved solids concentrations at sites on selected tributaries to Lake Ontario, New York, water years 2012-14...

14. Map showing mean annual yields of total suspended solids from sites on selected tributaries to Lake Ontario, New York, water years 2012-14

15. Map showing mean annual yields of phosphorus from sites on selected tributaries to Lake Ontario, New York, water years 2012-14.

16. Map showing mean annual yields of orthophosphate from sites on selected tributaries to Lake Ontario, New York, water years 2012-14.....

17. Map showing mean annual yields of total dissolved solids from sites on selected tributaries to Lake Ontario, New York, water years 2012-14..

\section{Tables}

1. Streamflow and water-quality monitoring sites on tributaries to Lake Ontario, New York, water years 2012-14

2. Land cover characteristics of selected basins in the Lake Ontario watershed, New York

3. Median constituent concentrations and physical measures by water year and summary statistics from concentrations in water samples from monitoring sites on tributaries to Lake Ontario, New York, water years 2012-14

4. Estimated annual constituent loads at monitoring sites tributary to Lake Ontario, New York, water years 2012-14, and statistically significant model variables

5. Annual mean loads and yields of selected constituents in composite discharge water samples from monitoring sites tributary to Lake Ontario, New York, water years 2012-14 


\section{Conversion Factors}

U.S. customary units to International System of Units

\begin{tabular}{|c|c|c|}
\hline Multiply & By & To obtain \\
\hline \multicolumn{3}{|c|}{ Length } \\
\hline inch (in.) & 2.54 & centimeter $(\mathrm{cm})$ \\
\hline foot $(\mathrm{ft})$ & 0.3048 & meter $(\mathrm{m})$ \\
\hline mile (mi) & 1.609 & kilometer $(\mathrm{km})$ \\
\hline \multicolumn{3}{|c|}{ Area } \\
\hline acre & 4,047 & square meter $\left(\mathrm{m}^{2}\right)$ \\
\hline acre & 0.4047 & square hectometer $\left(\mathrm{hm}^{2}\right)$ \\
\hline \multicolumn{3}{|c|}{ Volume } \\
\hline cubic foot $\left(\mathrm{ft}^{3}\right)$ & 0.02832 & cubic meter $\left(\mathrm{m}^{3}\right)$ \\
\hline \multicolumn{3}{|c|}{ Flow rate } \\
\hline cubic foot per second $\left(\mathrm{ft}^{3} / \mathrm{s}\right)$ & 0.02832 & cubic meter per second $\left(\mathrm{m}^{3} / \mathrm{s}\right)$ \\
\hline $\begin{array}{l}\text { cubic foot per second per } \\
\text { square mile }\left[\left(\mathrm{ft}^{3} / \mathrm{s}\right) / \mathrm{mi}^{2}\right]\end{array}$ & 0.01093 & $\begin{array}{l}\text { cubic meter per second per square kilometer } \\
{\left[\left(\mathrm{m}^{2} / \mathrm{s}\right) / \mathrm{km}^{2}\right]}\end{array}$ \\
\hline \multicolumn{3}{|c|}{ Mass } \\
\hline ton, short $(2,000 \mathrm{lb} ; \mathrm{t})$ & 0.9072 & metric ton \\
\hline ton per square mile $\left(\mathrm{t} / \mathrm{mi}^{2}\right)$ & 0.3503 & metric ton per square kilometer \\
\hline
\end{tabular}

Temperature in degrees Celsius $\left({ }^{\circ} \mathrm{C}\right)$ may be converted to degrees Fahrenheit $\left({ }^{\circ} \mathrm{F}\right)$ as ${ }^{\circ} \mathrm{F}=\left(1.8 \times{ }^{\circ} \mathrm{C}\right)+32$.

Temperature in degrees Fahrenheit $\left({ }^{\circ} \mathrm{F}\right)$ may be converted to degrees Celsius $\left({ }^{\circ} \mathrm{C}\right)$ as ${ }^{\circ} \mathrm{C}=\left({ }^{\circ} \mathrm{F}-32\right) / 1.8$.

\section{Datum}

Vertical coordinate information is referenced to the North American Vertical Datum of 1988 (NAVD 88).

Horizontal coordinate information is referenced to the North American Datum of 1983 (NAD 83).

Elevation, as used in this report, refers to distance above the vertical datum.

\section{Supplemental Information}

Specific conductance is given in microsiemens per centimeter at 25 degrees Celsius $\left(\mu \mathrm{S} / \mathrm{cm}\right.$ at $\left.25^{\circ} \mathrm{C}\right)$.

Concentrations of chemical constituents in water are given in milligrams per liter (mg/L). 


\section{Abbreviations}

$\begin{array}{ll}\text { AOC } & \text { area of concern } \\ \text { BMP } & \text { best management practice } \\ \text { EPA } & \text { U.S. Environmental Protection Agency } \\ \text { GLRI } & \text { Great Lakes Restoration Initiative } \\ \text { MRLC } & \text { Multi-Resolution Land Characteristics Consortium } \\ \text { NHD } & \text { National Hydrography Dataset } \\ \text { NLCD } & \text { National Land Cover Database } \\ \text { NYS } & \text { New York State } \\ \text { NYDEC } & \text { New York State Department of Environmental Conservation } \\ \text { USGS } & \text { U.S. Geological Survey }\end{array}$




\title{
Streamflow and Estimated Loads of Phosphorus and Dissolved and Suspended Solids From Selected Tributaries to Lake Ontario, New York, Water Years 2012-14
}

\author{
By Brett A. Hayhurst, Benjamin N. Fisher, and James E. Reddy
}

\section{Abstract}

This report presents results of the evaluation and interpretation of hydrologic and water-quality data collected as part of a cooperative program between the U.S. Geological Survey and the U.S. Environmental Protection Agency. Streamflow, phosphorus, and solids dissolved and suspended in stream water were the focus of monitoring by the U.S. Geological Survey at 10 sites on 9 selected tributaries to Lake Ontario during the period from October 2011 through September 2014. Streamflow yields (flow per unit area) were the highest from the Salmon River Basin due to sustained yields from the Tug Hill aquifer. The Eighteenmile Creek streamflow yields also were high as a result of sustained base flow contributions from a dam just upstream of the U.S. Geological Survey monitoring station at Burt. The lowest streamflow yields were measured in the Honeoye Creek Basin, which reflects a decrease in flow because of withdrawals from Canadice and Hemlock Lakes for the water supply of the City of Rochester. The Eighteenmile Creek and Oak Orchard Creek Basins had relatively high yields due in part to groundwater contributions from the Niagara Escarpment and seasonal releases from the New York State Barge Canal.

Annual constituent yields (load per unit area) of suspended solids, phosphorus, orthophosphate, and dissolved solids were computed to assess the relative contributions and allow direct comparison of loads among the monitored basins. High yields of total suspended solids were attributed to agricultural land use in highly erodible soils at all sites. The Genesee River, Irondequoit Creek, and Honeoye Creek had the highest concentrations and largest mean yields of total suspended solids (165 short tons per square mile [t/mi $\left.{ }^{2}\right]$, $184 \mathrm{t} / \mathrm{mi}^{2}$, and $89.7 \mathrm{t} / \mathrm{mi}^{2}$, respectively) of the study sites.

Samples from Eighteenmile Creek, Oak Orchard Creek at Kenyonville, and Irondequoit Creek had the highest concentrations and largest mean yields of phosphorus $\left(0.27 \mathrm{t} / \mathrm{mi}^{2}\right.$, $0.26 \mathrm{t} / \mathrm{mi}^{2}$, and $0.20 \mathrm{t} / \mathrm{mi}^{2}$, respectively) and orthophosphate $\left(0.17 \mathrm{t} / \mathrm{mi}^{2}, 0.13 \mathrm{t} / \mathrm{mi}^{2}\right.$, and $0.04 \mathrm{t} / \mathrm{mi}^{2}$, respectively) of the study sites. These results were attributed to a combination of sources, including discharges from wastewater treatment plants, diversions from the New York State Barge Canal, and manure and fertilizers applied to agricultural land. Yields of phosphorus also were high in the Genesee River Basin $\left(0.17 \mathrm{t} / \mathrm{mi}^{2}\right)$ and were presumably associated with nutrient and sediment transport from agricultural land and from streambank erosion. The Salmon and Black Rivers, which drain a substantial amount of forested land and are influenced by large groundwater discharges, had the lowest concentrations and yields of phosphorus and orthophosphate of the study sites.

Mean annual yields of dissolved solids were the highest in Irondequoit Creek due to a high percentage of urbanized area in the basin and in Oak Orchard Creek at Kenyonville and in Eighteenmile Creek due to groundwater contributions from the Niagara Escarpment. High yields of dissolved solids of $840 \mathrm{t} / \mathrm{mi}^{2}, 829 \mathrm{t} / \mathrm{mi}^{2}$, and $715 \mathrm{t} / \mathrm{mi}^{2}$, respectively, from these basins can be attributed to seasonal chloride yields associated with use of road deicing salts. The Niagara Escarpment can produce large amounts of dissolved solids from the dissolution of minerals (a continual process reflected in base flow samples). Groundwater inflows in the Salmon River have very low concentrations of dissolved solids due to minimal bedrock interaction along the Tug Hill Plateau and discharge from the Tug Hill sand and gravel aquifer, which has minimal mineralization.

\section{Introduction}

Lake Ontario is the easternmost Great Lake, has a direct drainage area of 24,720 square miles ( $\mathrm{mi}^{2}$; excluding the Niagara River and upper Great Lakes watershed), and is bounded by the Canadian Province of Ontario to the north and west and New York State to the south and east. Lake Ontario receives its primary inflow from the watersheds of the upper 
Great Lakes through the Niagara River near Youngstown, a drainage area of $263,700 \mathrm{mi}^{2}$. The U.S. Environmental Protection Agency (EPA) is administering a program called the Great Lakes Restoration Initiative (GLRI), which was launched in 2010 to accelerate efforts to protect and restore the health of all the Great Lakes through the GLRI action plans I and II (Great Lakes Interagency Task Force, 2014, undated). The GLRI action plans call for reductions in nutrient runoff from wastewater treatment discharges, combined storm and sanitary sewer overflows, and major nonpoint sources of pollution from urban and agricultural areas. Urbanization often increases the quantity of chemicals that can be deposited by atmospheric deposition or applied to the land surface. Urbanized impervious surfaces typically increase the hydraulic efficiency of water moving from the land surface to drainage systems and decrease travel time in streams; this can result in an increase in chemical loads carried into and out of a watershed. Agricultural activities can increase loads of nutrients, pesticides, and sediments to streams. Local, State, and Federal agencies have worked to create best management practices (BMPs) that focus on urban stormwater management, erosion control, and nutrient and sediment management on agricultural land. These practices would presumably benefit overall water quality in stream systems; however, monitoring of these practices has not been done on a regular basis in order to quantify the effectiveness of these BMPs over time.

In 2011, the EPA began a program in cooperation with the U.S. Geological Survey (USGS) to monitor, evaluate, and interpret hydrologic and water-quality data collected from sites at selected tributaries to Lake Ontario. Water-quality data were used to calculate constituent loads from major New York tributaries to Lake Ontario (fig. 1). Results from the monitoring program have been compiled in this report that covers the water years 2012-14. ${ }^{1}$ Sites selected specifically for this Lake Ontario monitoring program included Eighteenmile Creek, Oak Orchard Creek at Kenyonville and Shelby, Salmon River, and Black River. In addition to these, several other sites with established water-quality monitoring programs were included in this study. These latter sites included the Genesee River (7 years of record), the Oswego River (4 years), Honeoye Creek (16 years), and Allen and Irondequoit Creeks (33 years each). The hydrologic and water-quality information collected at these sites are used by water resources managers to make decisions regarding flood hazard and mitigation, low-flow drought conditions and management, mitigation of streambank erosion, and nonpoint-source pollution control.

Purpose and scope. - This report describes the hydrologic and water-quality conditions at 10 surface-water monitoring sites on selected tributaries to Lake Ontario during the water years 2012-14. The report presents (1) the methods of data collection, processing, and analysis and the statistical methods used for estimations of constituent loads; (2) summaries of climate records and climate trends, streamflow records, and

\footnotetext{
${ }^{1} \mathrm{~A}$ water year is the period from October 1 to September 30, numbered for the year in which the water year ends.
}

water-quality data; and (3) estimation of tributary loads and comparison of yields for streamflow and phosphorus, orthophosphate, dissolved solids, and suspended solids loads.

\section{Study Area}

The New York portion of the Lake Ontario watershed encompasses 12,560 $\mathrm{mi}^{2}$, excluding contributions from Lake Erie and the Niagara River (U.S. Department of Agriculture, Natural Resources Conservation Service, 2015). The sites that comprise the water-quality monitoring network on the selected tributaries to Lake Ontario in New York are shown in figure 1. Two streams, Honeoye Creek and Allen Creek, are actually tributaries to the Genesee River and Irondequoit Creek, respectively, which are themselves tributaries to Lake Ontario. There are two monitoring sites on Oak Orchard Creek, the upstream location at the village of Shelby and the downstream site at the hamlet of Kenyonville (fig. 1). The drainage areas covered by the 10 monitoring sites are a total of $10,105 \mathrm{mi}^{2}$, or 83 percent of the area of New York that drains to the lake (table 1).

\section{Land Cover}

The 2011 National Land Cover Database (NLCD 2011) was acquired to calculate land cover characteristics for the 10 watersheds associated with the surface-water monitoring sites (fig. 2; table 2). The NLCD 2011 is the most recent Landsat-based, 30-meter $(\mathrm{m})$ resolution land cover dataset for the entire United States developed by the Multi-Resolution Land Characteristics Consortium (MRLC; Homer and others, 2015). The NLCD 2011 uses a 16-class land cover classification scheme for the contiguous United States. For the purposes of this study, that classification scheme was abridged to six classes, consisting of open water, developed, barren, forest, agriculture, and wetlands. Land cover class acreages and percent area calculations for each of the 10 watersheds are listed in table 2 .

\section{Selected Watersheds}

The watersheds associated with the 10 surface-water monitoring sites were delineated using 30-meter (m) resolution elevation data from the National Hydrography Dataset Plus version 2 (NHDPlusV2; fig. 1). NHDPlusV2 is an integrated suite of geospatial data products, which incorporates features of the National Hydrography Dataset, the National Elevation Dataset, and the National Watershed Boundary Dataset (Dewald and others, 2012). Each of the 10 watersheds represents the drainage area upstream from the corresponding surface-water monitoring site. 

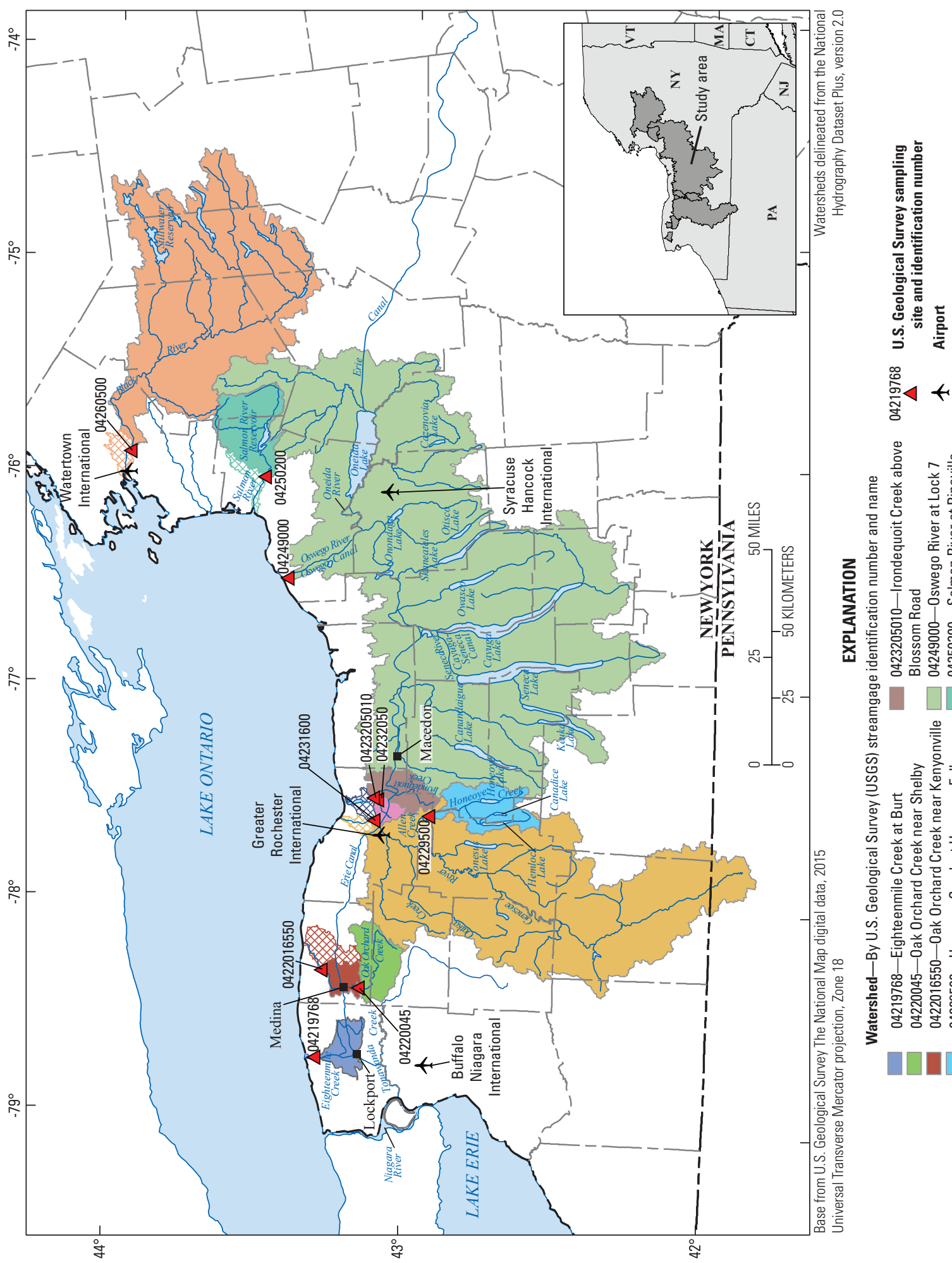

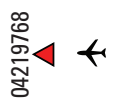

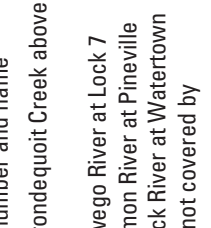

玄

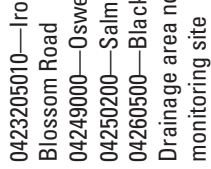
兽口 口冋口

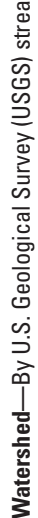

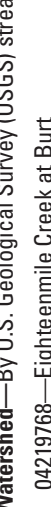
禀

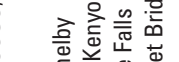
志的䓌岕离 美

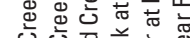

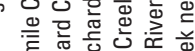

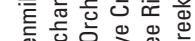

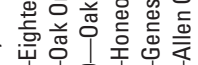
옹 安品응응

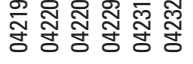
प०D०० 
Table 1. Streamflow and water-quality monitoring sites on tributaries to Lake Ontario, New York, water years 2012-14.

[Site locations are shown in figure 1. NAD27, North American Datum of 1927; NAD83, North American Datum of 1983; mi², square miles; $\mathrm{ft}^{3} / \mathrm{s}$, cubic feet per second]

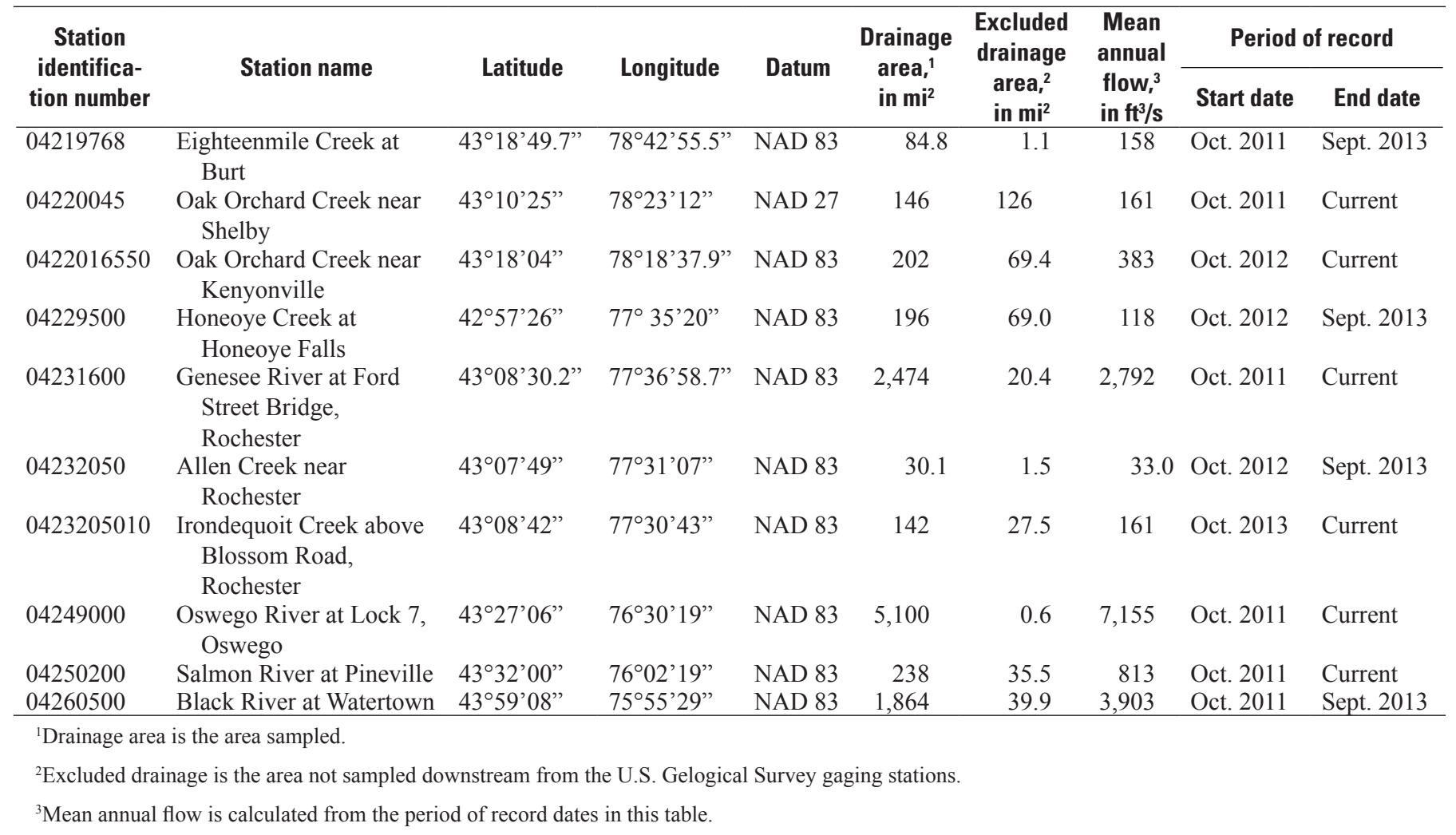

\section{Tributaries to Lake Ontario}

Eighteenmile Creek, which flows northward from its origin near the Lockport Dolostone Escarpment (referred to as the Niagara Escarpment in this report) shown in figure 3, has a drainage area of $84.8 \mathrm{mi}^{2}$ with more than 50.0 percent of its total land cover in agriculture uses and was designated an area of concern by the International Joint Commission after numerous contaminants were identified in creek sediments. Substantial groundwater contributions that sustain base flow during most of the year originate from the Niagara Escarpment.

Two monitoring sites are within the Oak Orchard Creek Basin: the upstream site at Shelby and the downstream site at Kenyonville. The creek flows west and then north from State and Federal wetland areas and then flows over the Niagara Escarpment (fig. 3; Cadwell, 1999) in a series of waterfalls just north of the Town of Shelby. Substantial groundwater contributions originate in this basin from the Onondaga Limestone Escarpment (fig. 3), which sustains base flows at least during spring of each year (Kappel and Jennings, 2012), as well as from the Niagara Escarpment, which contributes to base flows year round. Oak Orchard Creek at Shelby has a drainage area of $146 \mathrm{mi}^{2}$ that consist of 58.1 percent agricultural land and
27.3 percent wetlands. The downstream monitoring site at Kenyonville adds $56 \mathrm{mi}^{2}$ to the monitored drainage area (total drainage area of $202 \mathrm{mi}^{2}$ at this location) and a 7.75-percent increase in agricultural land, which represents 65.9 percent of the entire Oak Orchard Creek watershed at Kenyonville. Upstream from Kenyonville, the creek flows under the New York State Barge Canal directly into Glenwood Lake. The stream receives periodic overflow from the New York State Barge Canal during the canal operating season (April through November) each year.

The Genesee River flows northward from northwestern Pennsylvania and enters Lake Ontario at the city of Rochester and has a drainage area of $2,474 \mathrm{mi}^{2}$ at the USGS monitoring station in Rochester. The land use in the basin is primarily forested and agriculture at 40.8 percent and 46.6 percent, respectively. The Genesee River is a large source of sediment to Lake Ontario (New York State Department of Environment Conservation, 2003). The sediment consists of highly erodible, glacially derived lacustrine clay and silt soils on the valley floor through which the river flows for much of its length (fig. 4). Some subbasins have moderately sloped hillsides in the agricultural landscape which also contributes to additional sediment erosion and runoff. Honeoye Creek, encompasses 


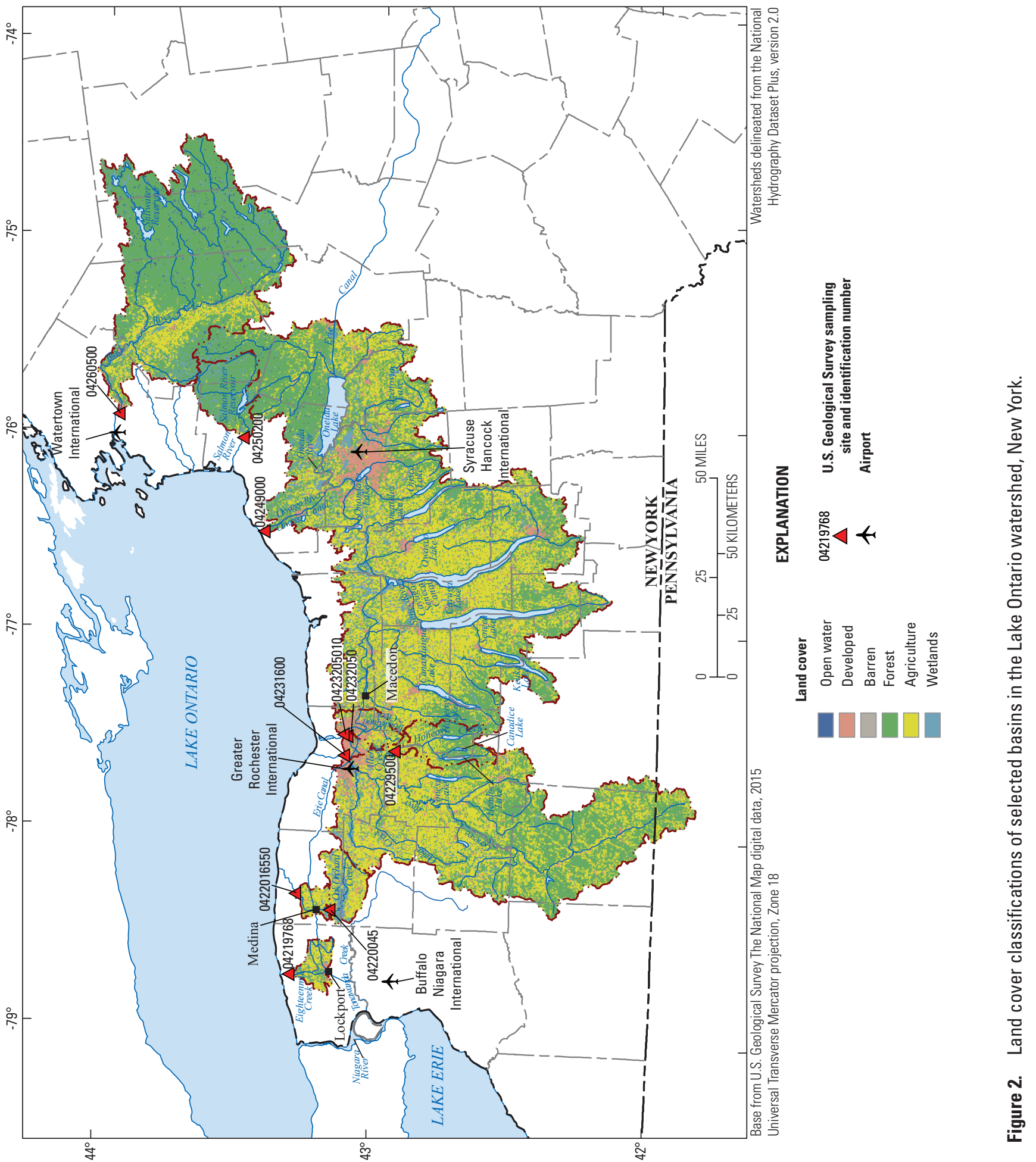




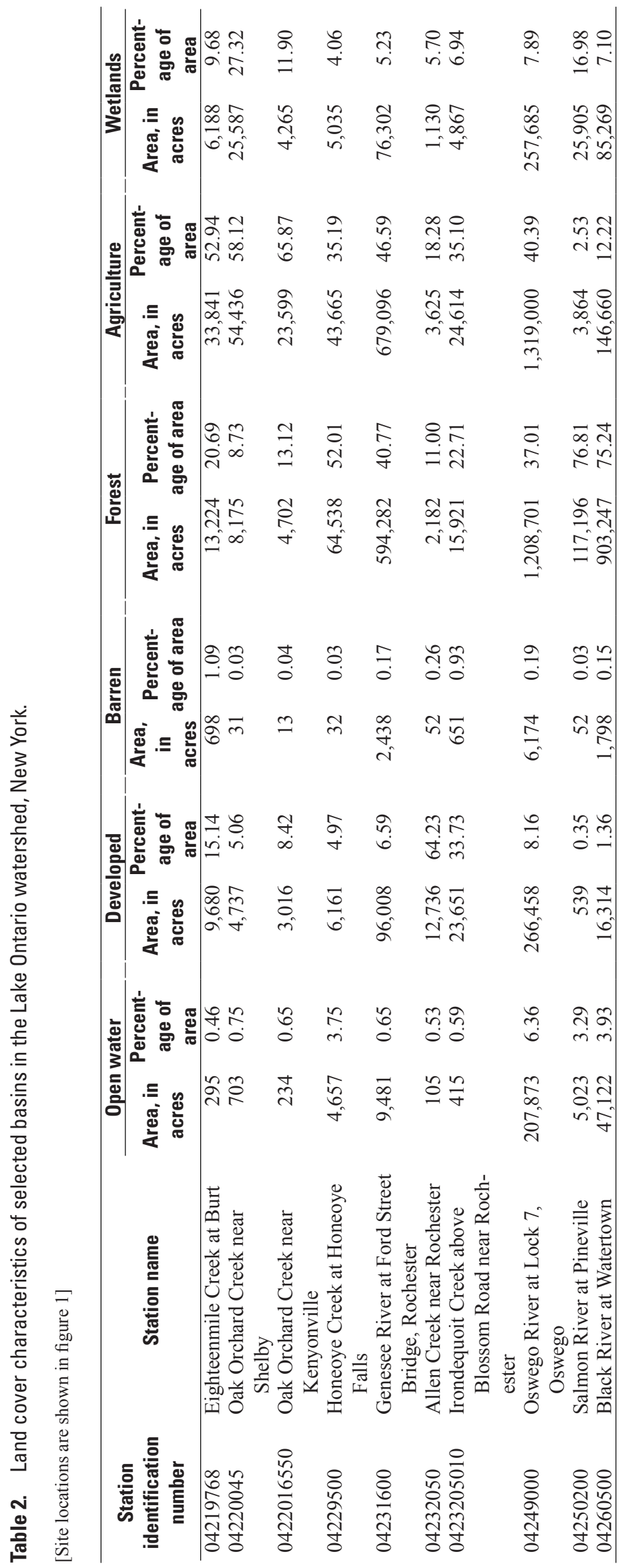




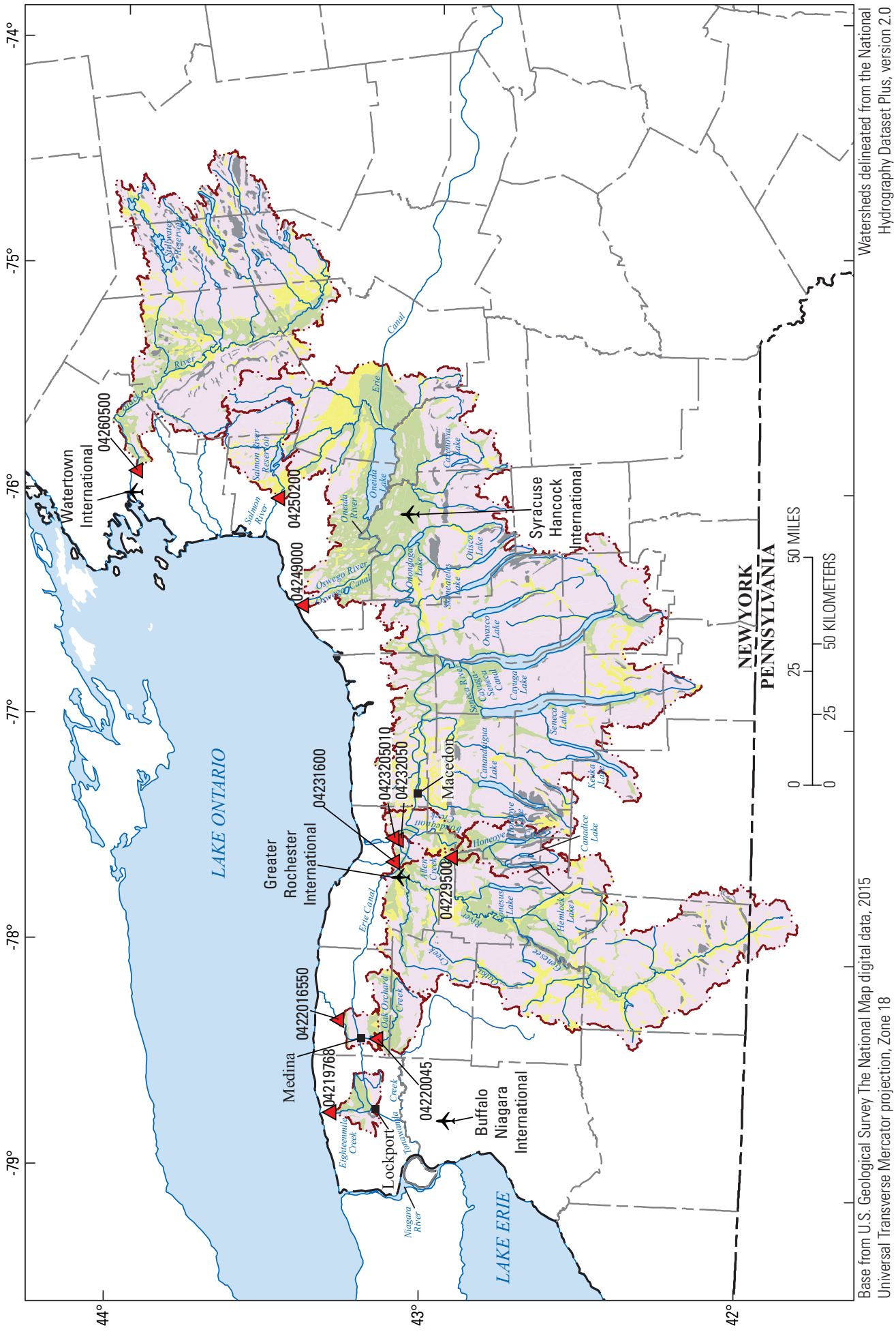

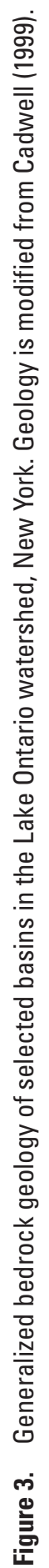




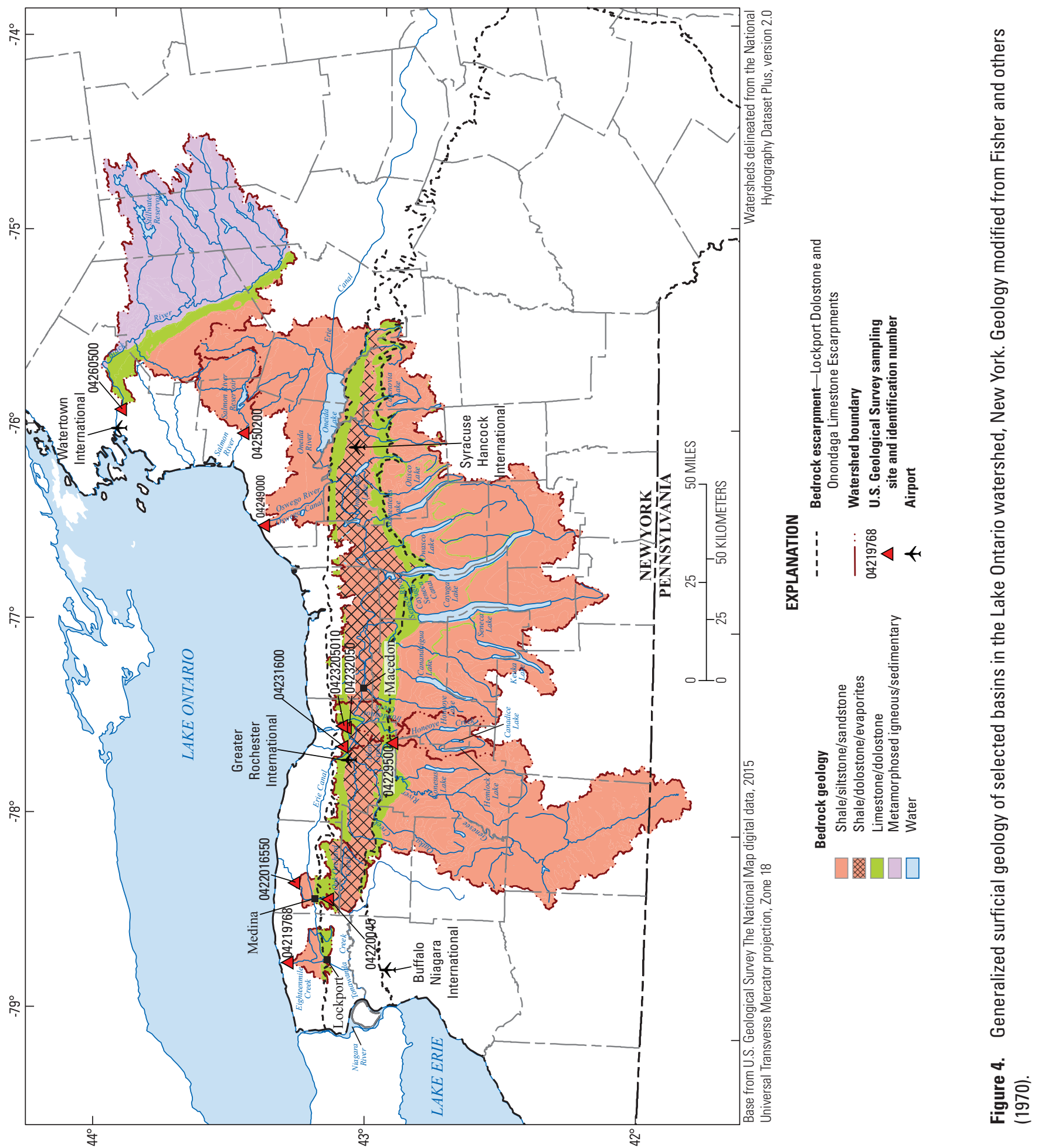


$196 \mathrm{mi}^{2}$ at its monitoring site at Honeoye Falls (fig. 1), and is a tributary of the Genesee River in southwestern Monroe County, with 35.0 percent of its watershed in agriculture and 52.0 percent forested (fig. 2).

The Irondequoit Creek Basin is directly east of the Genesee River at Rochester and encompasses $142 \mathrm{mi}^{2}$ of drainage area at Blossom Road near Rochester before it enters a wetland area and thence Irondequoit Bay and finally Lake Ontario. The land use transitions from forest and agriculture in the southern third of the basin to a densely urbanized area in the northern half. Allen Creek, a tributary of Irondequoit Creek, drains $30.1 \mathrm{mi}^{2}$, of which 64 percent is developed land, at its monitoring site near Rochester. Approximately 33.7 percent of the Irondequoit Creek Basin is developed land, and half of that developed drainage covers the Allen Creek Basin.

The Oswego River Basin drains 5,100 $\mathrm{mi}^{2}$ and is the largest basin draining to Lake Ontario from New York. The drainage area has the greatest percentage of open water, which includes seven of the central and eastern Finger Lakes and Oneida Lake. Agricultural land use and forested land dominate the land types in the basin at 40.4 percent and 37.0 percent, respectively (table 2 ).

The Salmon River and the Black River flow from east to the west and drain $238 \mathrm{mi}^{2}$ and 1,864 $\mathrm{mi}^{2}$, respectively, and are dominated by forested areas at 76.8 percent and 75.2 percent, respectively. The Salmon River receives 17 percent of its drainage from wetlands and springs that discharge from the Tug Hill aquifer. The percentages of agricultural and developed land uses in these two basins are less than those of the eight other basins in this study.

\section{Influences of New York State Barge Canal}

The New York State Barge Canal flows eastward from the Niagara River, across six of the basins monitored in northwestern New York (fig. 1). Water is diverted from the Niagara River and Tonawanda Creek on the west and into the New York State Barge Canal. The barge canal then flows through the Eighteenmile Creek and Oak Orchard Creek Basins and discharges into the Genesee River south of Rochester. The Genesee River and the barge canal meet at grade or relative river elevation of the Genesee River, as all canal flow from the west enters the Genesee River, and a corresponding amount of flow from the Genesee River enters the eastern continuation of the barge canal and flows eastward through the Allen Creek and Irondequoit Creek Basins and eventually into the Oswego River Basin. Overflow spillways and siphons along the canal permit canal water to flow into the monitored tributary basins. During the navigation season (from late April to mid-November), daily flows in the canal east of the Genesee River typically range from 200 to 300 cubic feet per second $\left(\mathrm{ft}^{3} / \mathrm{s}\right)$ according to data from the USGS gaging station at Lock 30 at Macedon (station number 04219000; U.S. Geological Survey, 2014a). From Macedon, the canal flows eastward into the Oswego River Basin joining with outflows from several Finger Lakes and other streams, which enter this canalized river segment of the canal. Eventually the barge canal and the Seneca River are one and the same as they flow eastward toward Syracuse (fig. 1). As the barge canal flows north of Syracuse the canal joins the Oneida River and flows further east to Oneida Lake where the canal steps through a series of locks crossing a major watershed divide from the Oswego River Basin and into the Mohawk River Basin as it flows east toward Albany and on to the Hudson River. At the confluence of the Seneca and Oneida Rivers, a section of the barge canal merges with the Oswego River, which continues northward to its mouth at Lake Ontario.

\section{Climate}

Climate data were obtained from the Northeast Regional Climate Center CLIMOD 2 (Northeast Regional Climate Center, 2015) for four National Weather Service locations: Buffalo Niagara International Airport (Buffalo Airport) east of the city of Buffalo, the Greater Rochester International Airport (Rochester Airport) southwest of the city of Rochester, the Syracuse Hancock International Airport (Syracuse Airport) northeast of the city of Syracuse, and the Watertown International Airport (Watertown Airport) west of the city of Watertown. The weather across northern and central New York is greatly affected by Lake Ontario, which has a moderating effect on air temperatures and inhibits the extreme temperature fluctuations that are recorded further inland. Lake Ontario rarely freezes completely during the winter months and contributes to overall snow distributions through lake-effect bands of snow, which are directed by prevailing wind patterns across the lake from west to east.

\section{Precipitation}

Average annual precipitation for Buffalo, Rochester, Syracuse, and Watertown Airports (1981-2010) is 40.5 inches (in.), 34.3 in., 38.5 in, and 36.1 in., respectively (Northeast Regional Climate Center, 2015). Monthly 30-year mean precipitation ranged from about $2.2 \mathrm{in}$. in February to about 3.8 in. from July to September (fig. $5 A-D$; Northeast Regional Climate Center, 2015).

Average annual precipitation totals during the 3-year study period (2012-14) were close to 30-year mean values; average totals for Buffalo, Rochester, Syracuse, and Watertown Airports were 41.3 in., 35.9 in., 38.5 in., and 38.2 in., respectively (Northeast Regional Climate Center, 2015). Lakeeffect storms can produce snowfalls exceeding 1 to $2 \mathrm{ft}$ in a 24-hour period near the lake and, by the end of the season, can account for more than half the total snowfall in these areas. Seasonal snowfall amounts can vary widely across the Lake Ontario watershed in New York, with generally the greatest amounts of snow (an average annual snowfall of 240 in.) falling on the Tug Hill Plateau directly east of Lake Ontario. 

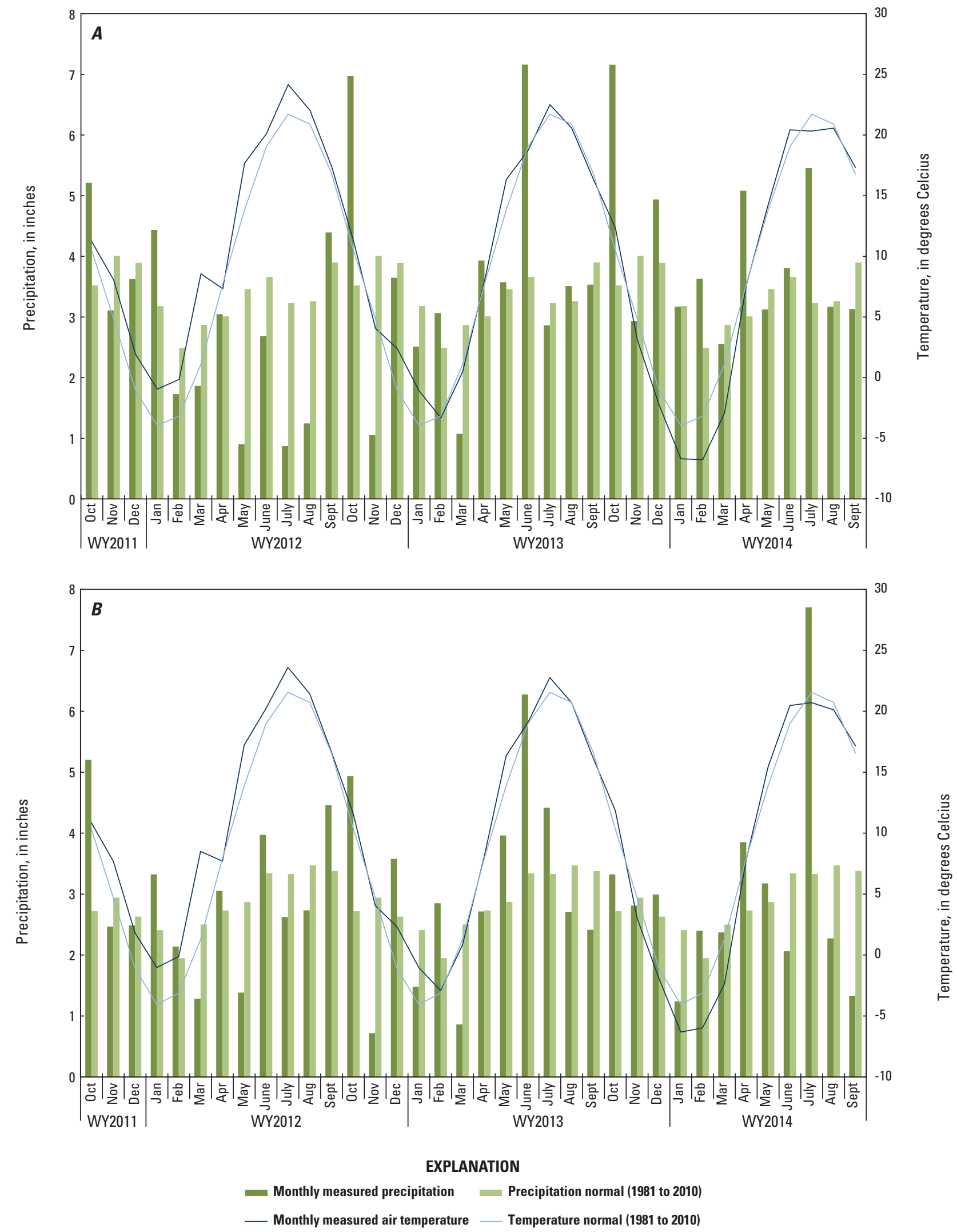

Figure 5. Precipitation and temperature at selected airports in New York: A, Monthly mean (water years [WYs] 2012-14) and normal (WYs 1981-2010) precipitation and temperature at Buffalo Niagara International Airport; B, monthly mean (WYs 2012-14) and normal (WYs 1981-2010) precipitation and temperature at Greater Rochester International Airport. 

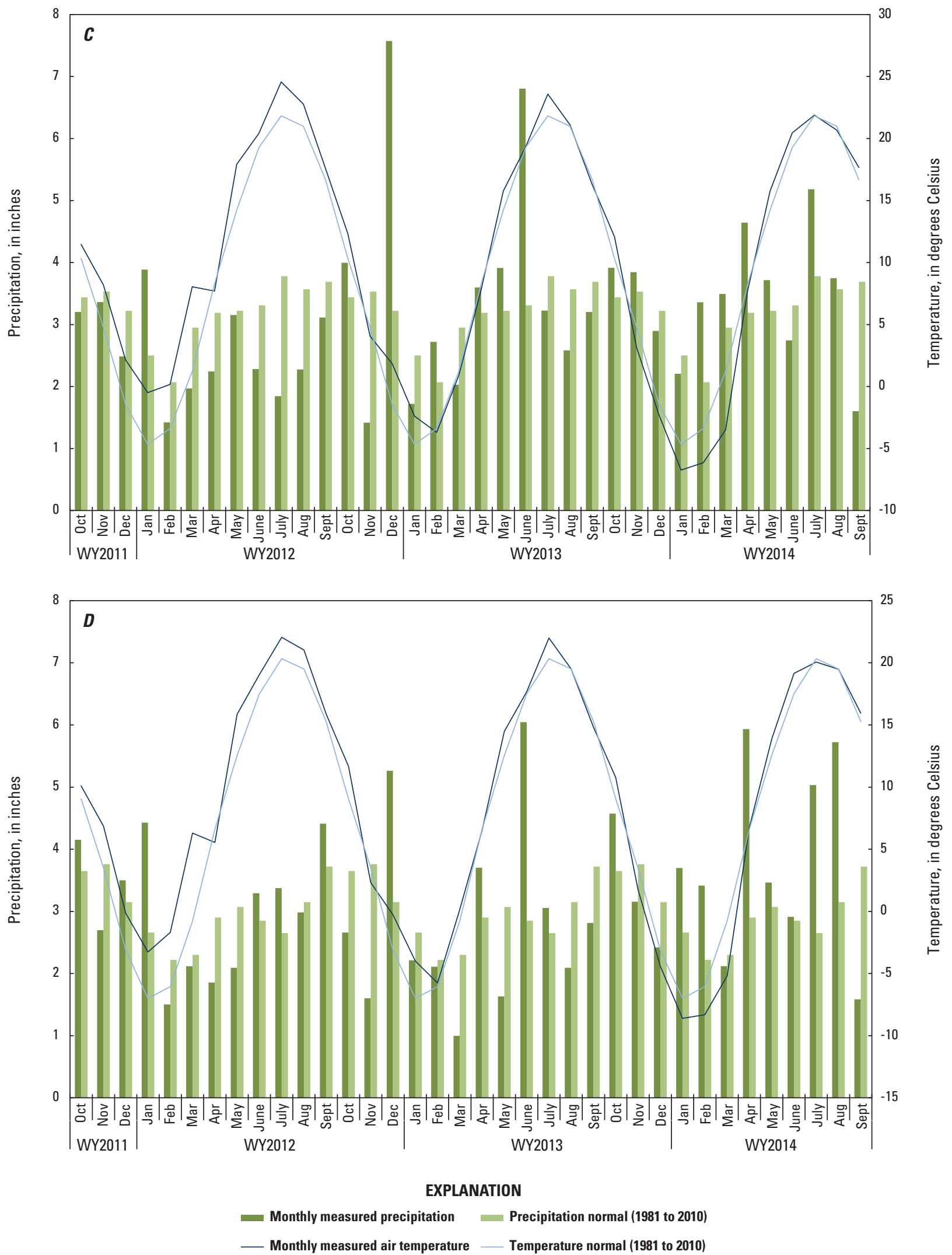

Figure 5. Precipitation and temperature at selected airports in New York: $C$, monthly mean (WYs 2012-14) and normal (WYs 1981-2010) precipitation and temperature at Syracuse Hancock International Airport; and D, monthly mean (WYs 2012-14) and normal (WYs 1981-2010) precipitation and temperature at Watertown International Airport.-Continued 


\section{Air Temperature}

The monthly low temperature in Buffalo, Rochester, and Syracuse was about -4 degrees Celsius $\left({ }^{\circ} \mathrm{C} ; 25\right.$ degrees Fahrenheit $\left.\left[{ }^{\circ} \mathrm{F}\right]\right)$ in January, and the monthly high temperature was about $22^{\circ} \mathrm{C}\left(71^{\circ} \mathrm{F}\right)$ in July. Temperatures in Watertown were generally lower during both periods: $-7^{\circ} \mathrm{C}\left(19^{\circ} \mathrm{F}\right)$ in January and $21^{\circ} \mathrm{C}\left(69^{\circ} \mathrm{F}\right)$ in July (Northeast Regional Climate Center, 2015).

During water years 2012-14 (Northeast Regional Climate Center, 2015), the largest monthly departure from the normal values at Buffalo, Rochester, Syracuse, and Watertown Airports occurred during March 2012 with average values of $8.6^{\circ} \mathrm{C}\left(47.4^{\circ} \mathrm{F}\right), 8.5^{\circ} \mathrm{C}\left(47.3^{\circ} \mathrm{F}\right), 8.1^{\circ} \mathrm{C}\left(46.5^{\circ} \mathrm{F}\right)$ and $6.3^{\circ} \mathrm{C}$ $\left(43.3^{\circ} \mathrm{F}\right)$, respectively. The 30 -year monthly normal temperature at Buffalo, Rochester, Syracuse, and Watertown Airports for March is $1.1^{\circ} \mathrm{C}\left(34.0^{\circ} \mathrm{F}\right), 1.3^{\circ} \mathrm{C}\left(34.3{ }^{\circ} \mathrm{F}\right), 1.2^{\circ} \mathrm{C}$ $\left(34.2^{\circ} \mathrm{F}\right)$, and $-0.8^{\circ} \mathrm{C}\left(30.6^{\circ} \mathrm{F}\right)$, respectively (fig. $\left.5 A-D\right)$.

\section{Data Collection and Processing}

Water levels at 10 monitoring sites and velocity at 1 site - the Genesee River at Rochester - were recorded continuously during the study period (fig. 1). Water-quality samples were collected at monthly intervals and analyzed for phosphorus, orthophosphate, total dissolved solids, and total suspended solids. Water-quality collections at Eighteenmile Creek, Oak Orchard Creek at Kenyonville, Allen Creek, Honeoye Creek, Irondequoit Creek, and the Black River had different start and end dates during the study due to funding limitations and annual changes in EPA program priorities (table 1). Water-quality samples were not collected at the sites on Eighteenmile Creek, Honeoye Creek, and Allen Creek, and on the Black River after September 2013.

\section{Stage and Streamflow}

The water levels at 10 locations and velocity at the Genesee River at Rochester streamgage (fig. 1) were measured every 15 minutes using standard USGS procedures (Sauer and Turnipseed, 2010) and recorded by an electronic data logger. Streamflow was measured regularly by the USGS according to procedures described in Rantz and others (1982), Turnipseed and Sauer (2010), and Mueller and others (2013). Stage, velocity, and streamflow data were compiled and streamflows were computed from either stage-discharge or stage-area and index-velocity discharge relations that were developed through standard USGS procedures (Sauer and Turnipseed, 2010; Levesque and Oberg, 2012). Daily mean streamflows (appendix 1) were computed from 15-minute discharges at all 10 monitoring locations, the exception being Oak Orchard Creek near Kenyonville where computations began in August 2012 and Eighteenmile Creek where the discharges ended in September 2013.

\section{Chemical Constituents}

Water samples were collected by refrigerated automatic samplers at four monitoring sites. Samplers were activated in anticipation of storm events at Genesee River at Rochester, Honeoye Creek at Honeoye Falls, Irondequoit Creek near Rochester, and Oswego River at Oswego. Samples were collected repeatedly during changes in stage for a given storm and stored in separate high-density polyethylene (HDPE) bottles. The frequency of samples varied throughout a given year over the length of this study. Quality-assurance water samples, collected from the stream on the first Monday of each month using the equal-width-increment method (U.S. Geological Survey, 2014a), were compared with water samples collected by the automatic samplers. All samples were analyzed by the USGS National Water Quality Laboratory in Lakewood, Colorado (appendix 2). Comparison of quality-assurance samples showed point samples collected by the automated samplers were representative of the "true" constituent concentrations as determined by the equal-widthincrement samples. The period of record (2011-14) was interrupted at four locations (table 1) with later startup dates at four locations. More than 100 samples were collected at Genesee River at Rochester, and as few as 17 samples were collected at Allen Creek near Rochester. The total number of discrete samples for all sites was 474 , with 28 additional qualityassurance samples; all sample results are stored in the USGS National Water Information System (U.S. Geological Survey, 2014b). Some additional data were compiled from outside the reporting dates of 2011-14 for the following locations and years: Honeoye Creek 2010-11, Genesee River 2011, Allen Creek 2010-11, Irondequoit Creek 2009-11, and the Oswego River 2010-11; these additional data were used for load modeling interpretation.

\section{Data Analyses}

Mean annual flows (table 1) at the 10 monitoring sites were computed and then normalized by their respective drainage basin area to account for differences in drainagearea size. Normalizing flow per unit area allows a direct comparison of yields among all 10 sites. Differences in yields could result from streamflow diversions or regulation, which occurred in nearly all the monitored watersheds, or from variability in precipitation and evapotranspiration across large basins. The Genesee River, for example, drains from the New York-Pennsylvania border where the mean annual precipitation is $32 \mathrm{in}$. and the mean annual runoff is $14 \mathrm{in}$. (Randall, 1996). The Oswego River has the largest drainage area, which includes 7 of the 11 Finger Lakes and Oneida Lake within its drainage area and has a mean annual precipitation of $34 \mathrm{in.} \mathrm{Seneca} \mathrm{and} \mathrm{Cayuga} \mathrm{Lakes} \mathrm{have} \mathrm{surface} \mathrm{areas} \mathrm{of}$ $67.6 \mathrm{mi}^{2}$ and $66.4 \mathrm{mi}^{2}$, respectively; these two lakes account for 90 percent of the total lake volume in the Oswego River 
Basin. Oneida Lake is the largest lake in New York with a surface area of $79.8 \mathrm{mi}^{2}$ and the shallowest of the lakes in the Oswego River Basin, and therefore has the highest potential evapotranspiration rate.

\section{Streamflow}

Mean annual streamflow at the 10 USGS monitoring sites ranges from 33.0 to $7,160 \mathrm{ft}^{3} / \mathrm{s}$ during the study period (table 1). The Oswego River has the highest mean annual flow $\left(7,160 \mathrm{ft}^{3} / \mathrm{s}\right)$, followed by the Black and Genesee Rivers with 3,900 ft $\mathrm{ft}^{3} / \mathrm{s}$ and $2,790 \mathrm{ft}^{3} / \mathrm{s}$, respectively. Allen Creek has the lowest mean annual flow $\left(33.0 \mathrm{ft}^{3} / \mathrm{s}\right)$ and is a tributary to Irondequoit Creek, which has similar mean annual flows compared with those for Eighteenmile and Oak Orchard Creek near Shelby, which have mean annual flows around $160 \mathrm{ft}^{3} / \mathrm{s}$ (table 1).

Monthly mean streamflow yield (fig. 6) for the study period demonstrates increased yields during the snowmelt and runoff events from March to May of each year. Winter temperatures were mild in 2012, and flows at all locations reflect a short period of snowmelt in February 2012. The overall trend for winter temperatures (fig. 5), however, decreases over the 3 water years (2012-14), pushing snowmelt later into each following spring season. One significant precipitation event occurred at all sites in June 2013 across the entire southern Lake Ontario Basin (fig. 5). Flows at the Salmon and Black Rivers increased from September 2013 to February 2014 as a result of increased precipitation during the leaf-off period.
Annual mean streamflow yield for water years 2012-14 ranges from 0.6 cubic foot per second per square mile $\left[\left(\mathrm{ft}^{3} / \mathrm{s}\right) /\right.$ $\left.\mathrm{mi}^{2}\right]$ at Honeoye Creek to $4.2\left(\mathrm{ft}^{3} / \mathrm{s}\right) / \mathrm{mi}^{2}$ at Salmon River (fig. 7). Honeoye Creek flow is affected by diversions of flow from Canadice Lake to Hemlock Lake for the water supply of the City of Rochester (figs. 6 and 8; Hayhurst and others, 2010).

The Salmon and Black Rivers have the highest annual mean streamflow yields, $4.2\left(\mathrm{ft}^{3} / \mathrm{s}\right) / \mathrm{mi}^{2}$ and $2.9\left(\mathrm{ft}^{3} / \mathrm{s}\right) / \mathrm{mi}^{2}$, respectively, in 2014, presumably due to groundwater contributions from the Tug Hill aquifer into the Salmon River and direct contributions from the Adirondack Mountains in the Black River Basin. Eighteenmile Creek and Oak Orchard Creek near Kenyonville have the third and fourth highest yields, which are attributed to sustained base flow contributions from the Niagara Escarpment in both basins. Both creeks have similar annual mean streamflow yields, averaging $2.0\left(\mathrm{ft}^{3} / \mathrm{s}\right) / \mathrm{mi}^{2}$ at Eighteenmile Creek at Burt and $1.9\left(\mathrm{ft}^{3} / \mathrm{s}\right) /$ $\mathrm{mi}^{2}$ at Oak Orchard Creek near Kenyonville for water years 2012-14 (fig. 7).

\section{Water Quality}

Water quality can be assessed by measurements of physical characteristics, such as water temperature and specific conductance, and by the concentrations of constituents, such as phosphorus, orthophosphate, total suspended solids, and total dissolved solids. The concentrations of constituents can be used to highlight differences in water quality in a basin and compare differences from basin to basin. Concentrations,

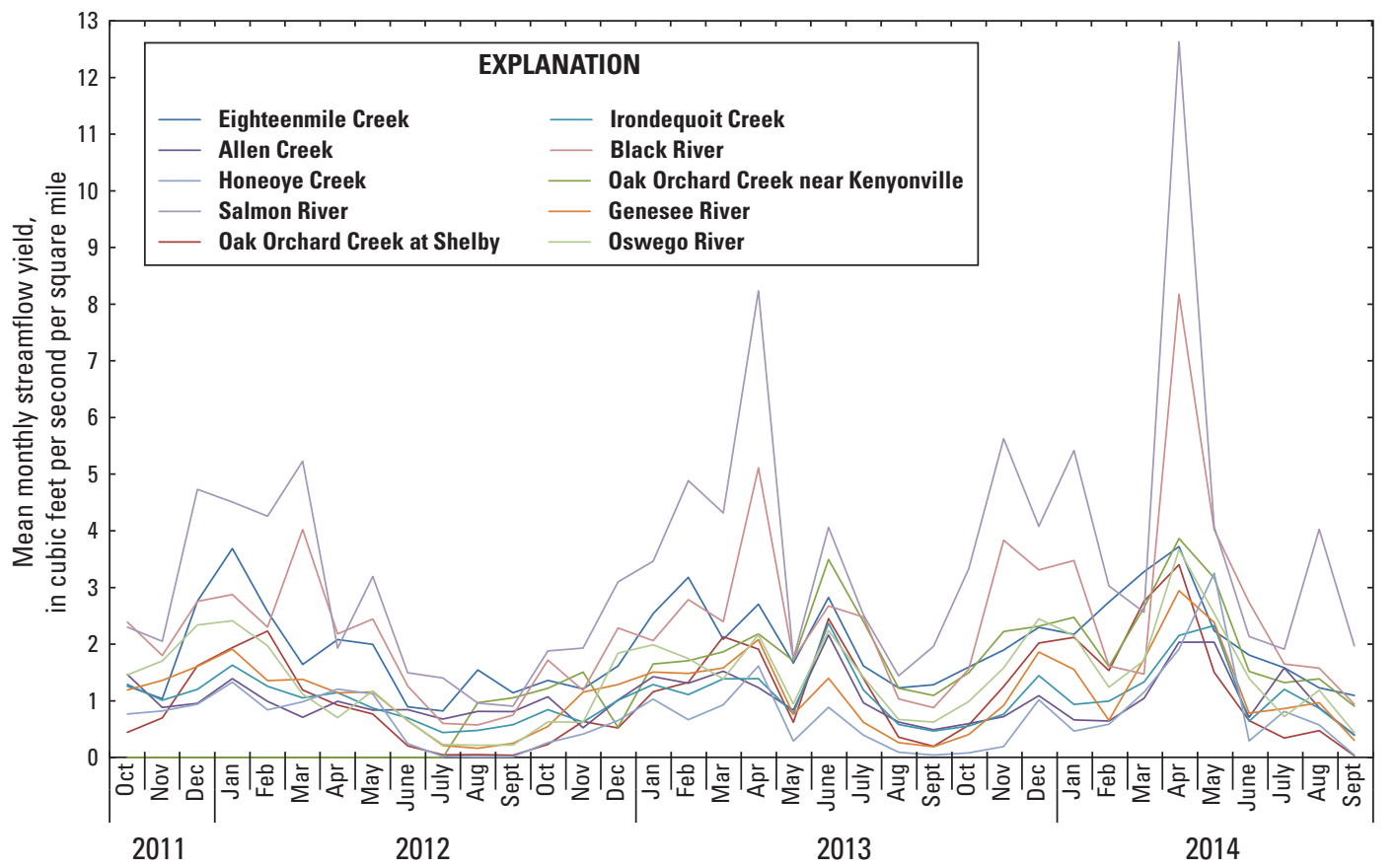

Figure 6. Monthly mean streamflow for selected tributaries to Lake Ontario, New York, water years 2012-14. 


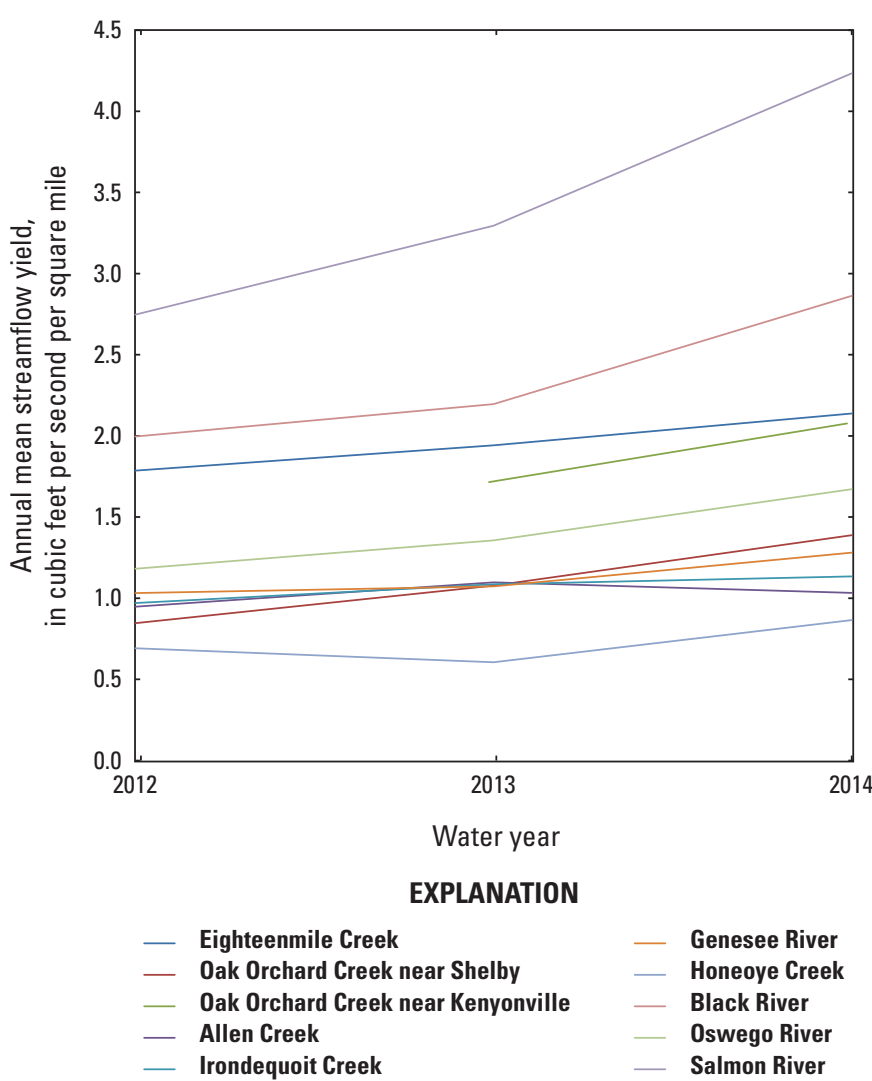

Figure 7. Annual mean streamflow yields for selected tributaries to Lake Ontario, New York, water years 2012-14.

measured in milligrams per liter, can then be used along with flows to obtain estimated loads of constituents. Estimated loads provide information about nutrient balance within a watershed. Those conditions are affected by climate, basin characteristics and land use, and physical disturbances whether natural or manmade.

\section{Water Temperature}

Water temperature can have direct effects on the solubility of constituents, the rate of chemical reactions, the level of organism activity in an aquatic environment, and the growth or death rates of organisms and microorganisms. Water temperatures can be affected by several factors, including groundwater contributions, precipitation types and rates, diurnal changes in air temperature and the amount of solar radiation contacting the stream, and the tributary inflow temperatures from both natural and manmade sources.

Temperatures have been collected when possible at the centroid of flow at the 10 sampling locations at the time the sample was collected (fig. 1). Water temperatures for sampled streamflow during water years 2012-14 (table 3) ranged from a low of $0.0^{\circ} \mathrm{C}\left(32.0^{\circ} \mathrm{F}\right)$ at Oak Orchard Creek near Shelby and Kenyonville, the Genesee River at Rochester, and the Oswego River at Oswego to a high of $27.5^{\circ} \mathrm{C}\left(81.5^{\circ} \mathrm{F}\right)$ at the Oswego River at Oswego.

\section{Specific Conductance}

Specific conductance, measured in microsiemens per centimeter at 25 degrees Celsius, is a standardized measure of the ability of water to conduct an electric current and is related to the amount of ions (atoms with negative [anion] or positive [cation] charges) dissolved in the water. Specific conductance was measured with a handheld instrument in the field, whereas the measurement of dissolved solids requires the collection of a water sample and analysis of the sample in a laboratory. The dissolved solids analysis uses an aliquot of total sample volume, which is filtered and the filter is dried. The amount of dried solids in the sample is weighed and reported in milligrams per liter. In either case, these measurements determine the general inorganic (ionic) content of the water. Figure 9 illustrates the median specific conductance for each tributary watershed monitored in this study.

The median specific conductances at Irondequoit Creek near Rochester, Oak Orchard Creek near Shelby, and Allen Creek near Rochester were 1,200 microsiemens per centimeter at 25 degrees Celsius $\left(\mu \mathrm{S} / \mathrm{cm}\right.$ at $\left.25^{\circ} \mathrm{C}\right), 1,130 \mu \mathrm{S} / \mathrm{cm}$ at $25^{\circ} \mathrm{C}$, and $946 \mu \mathrm{S} / \mathrm{cm}$ at $25^{\circ} \mathrm{C}$, respectively. The measure of conductance is highest at locations within urbanized watersheds where the chemistry of storm sewer runoff is greatly affected by road-deicing salt (sodium chloride) used during the winter months (Heisig, 2000). The Irondequoit Creek and Allen Creek watersheds have the greatest percentages of urban land use of the nine tributary watersheds (table 3). Oak Orchard Creek at Shelby has a high conductance year-round, but especially during base flow due to groundwater influences from the Lockport Dolostone and the Camillus Shale (gypsum) mineral contributions. Inorganic constituents from the groundwater influence in the upper Oak Orchard Creek Basin are high in calcium, magnesium, and sodium plus potassium (Hayhurst and others, 2010; Kappel and Jennings, 2012). The Salmon and Black Rivers have the lowest specific conductance because base flows are sustained by groundwater from sand and gravel aquifers, which have limited contact with bedrock that might otherwise supply ionized minerals to these streams. Low concentrations in chlorides can be expected in these relatively undeveloped watersheds.

\section{Nutrients, Total Suspended Solids, and Total Dissolved Solids}

Oak Orchard Creek near Shelby had the highest median annual concentrations of phosphorus, orthophosphate, and total dissolved solids of the 10 monitored sites (figs. 10-13; table 3). The concentrations decrease downstream at Oak Orchard Creek near Kenyonville for all constituents analyzed 

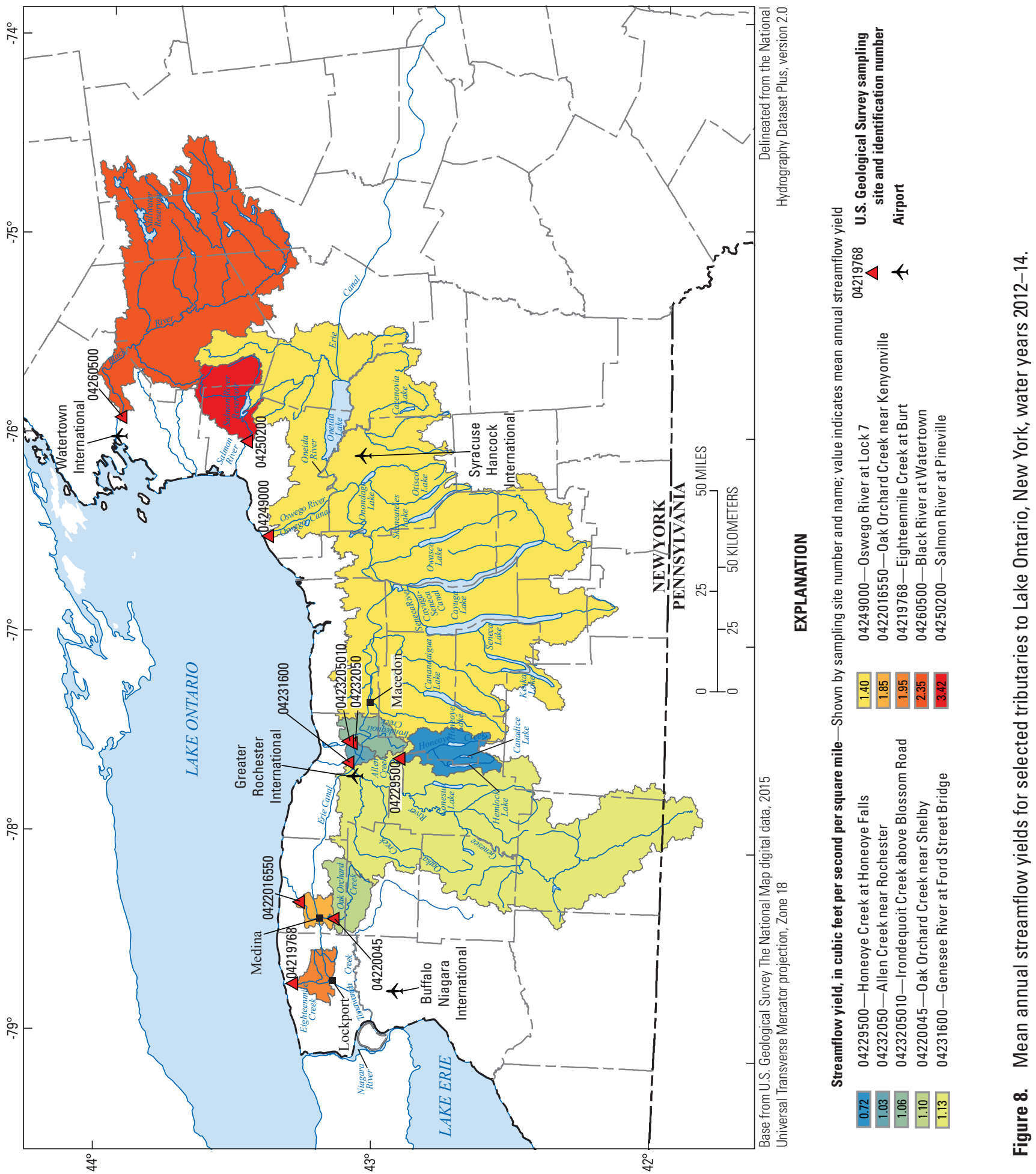


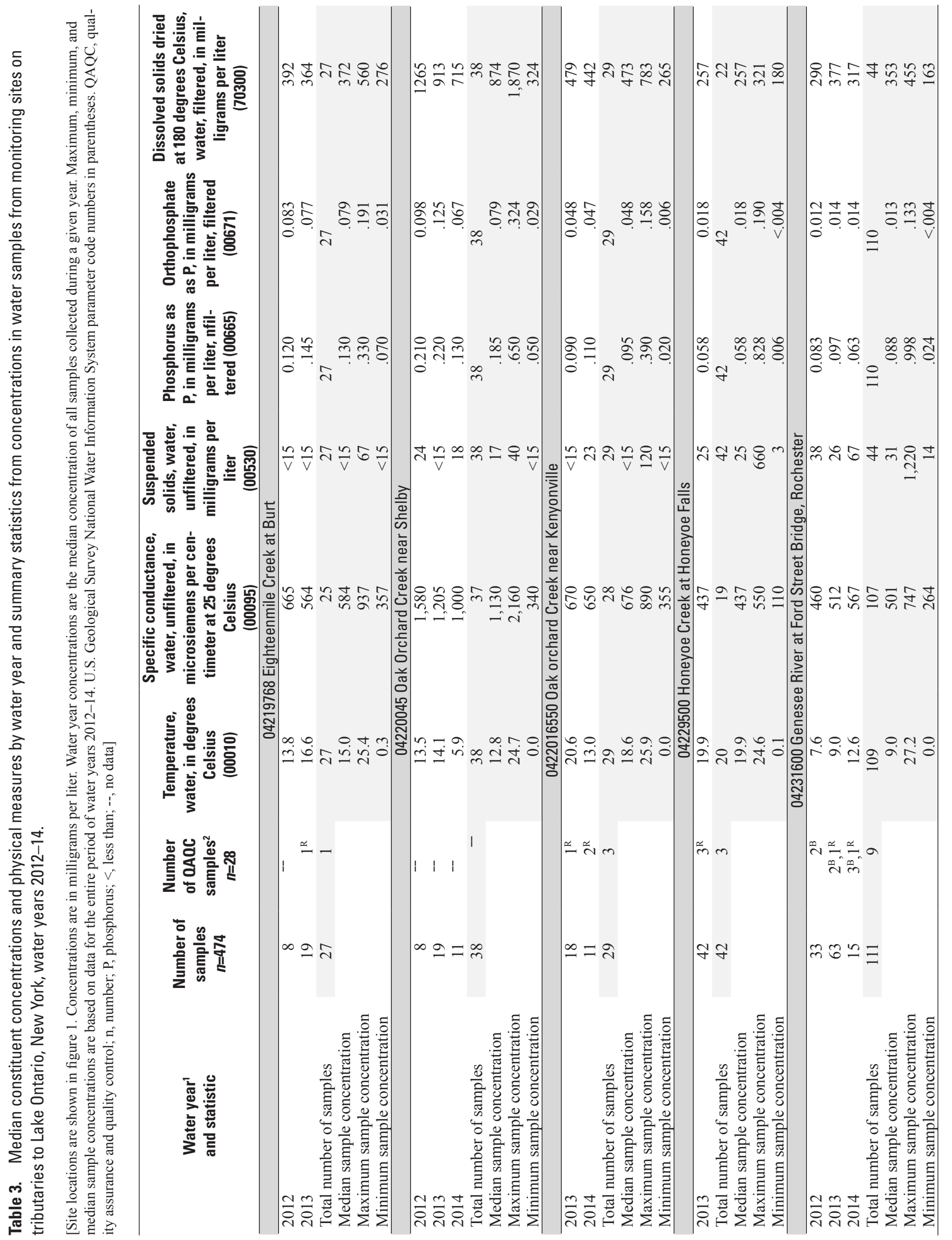




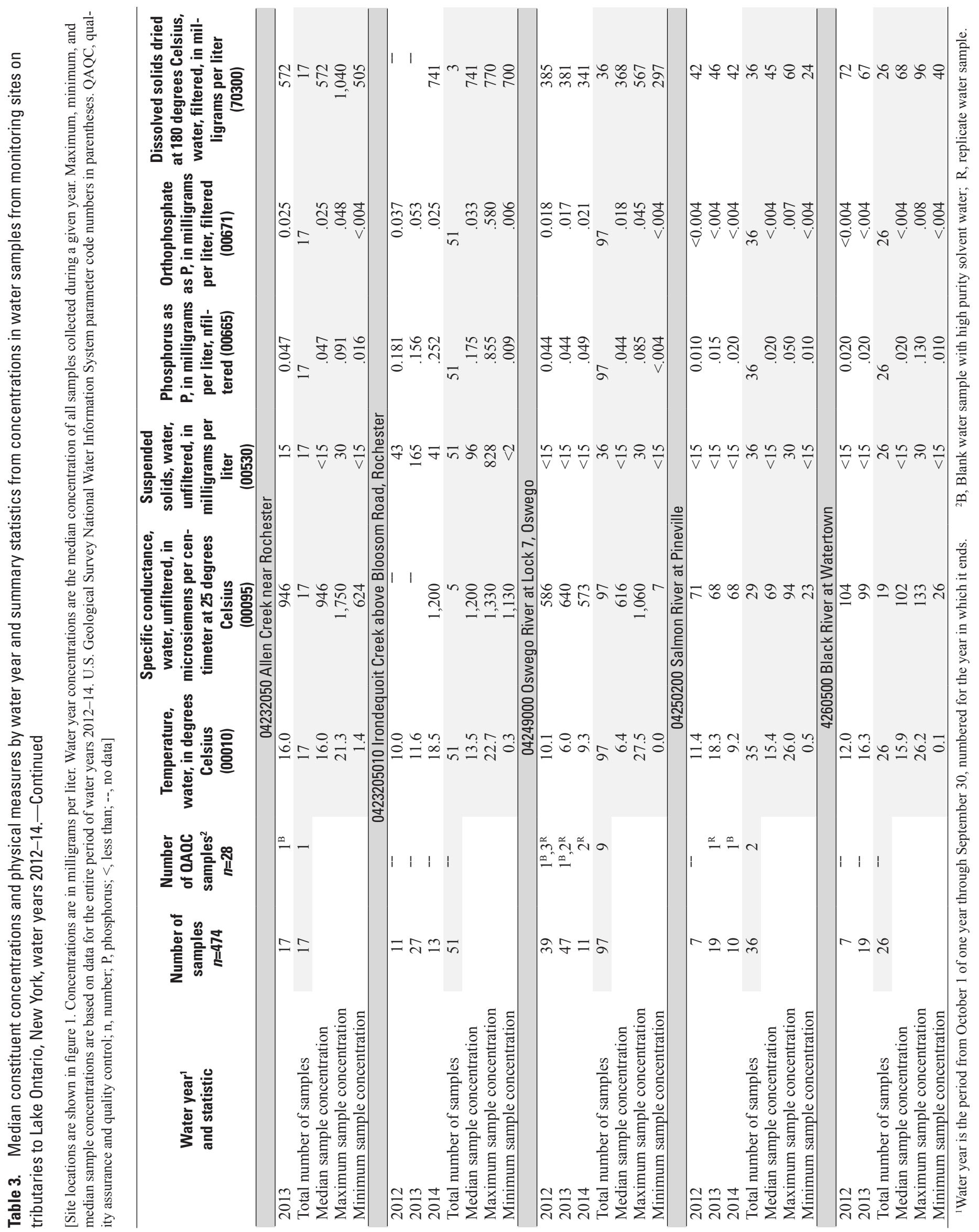




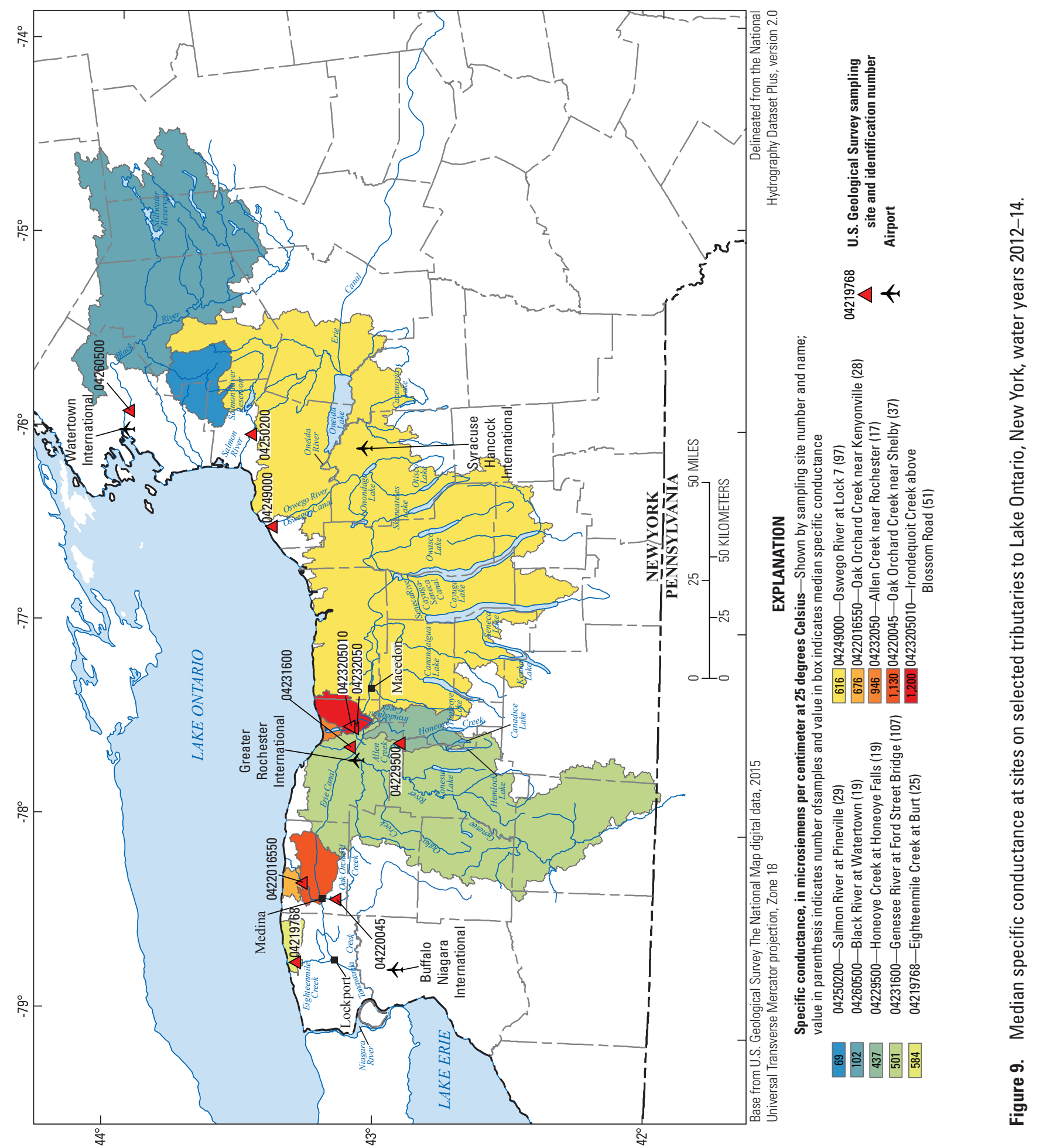



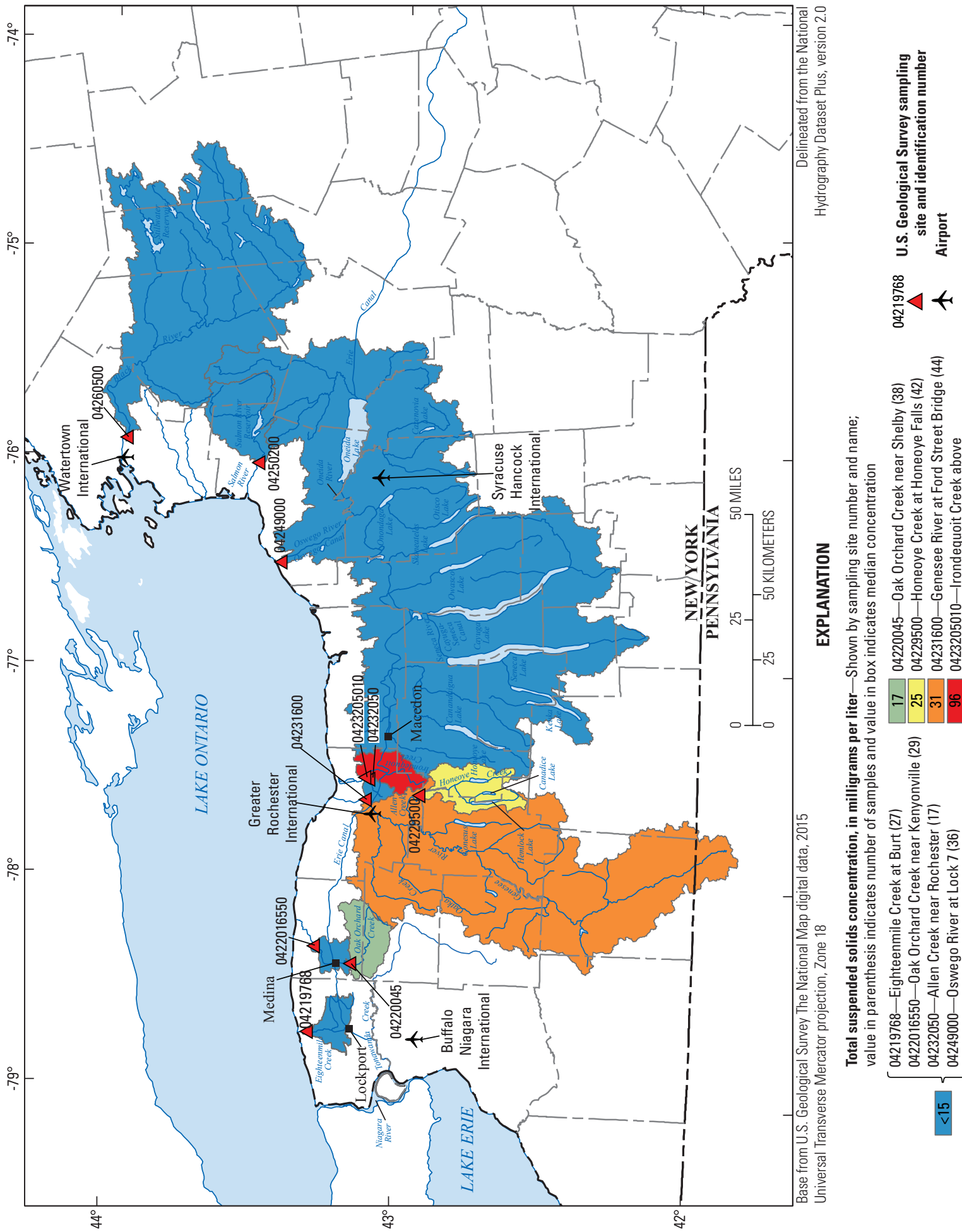

i.

政

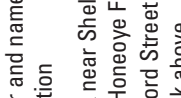

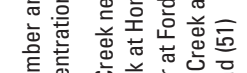

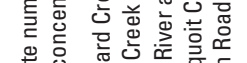

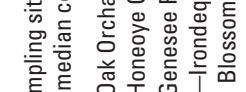

要离 1110

究.

का

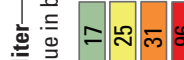

亲产

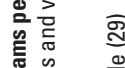

矛哂

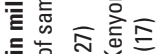

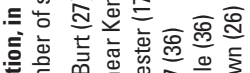

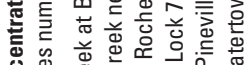

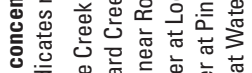

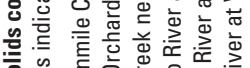

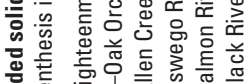

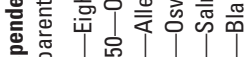

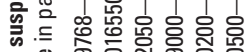

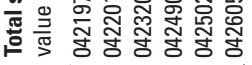

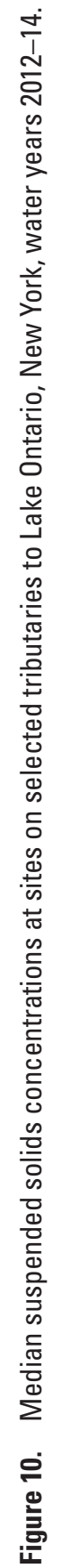



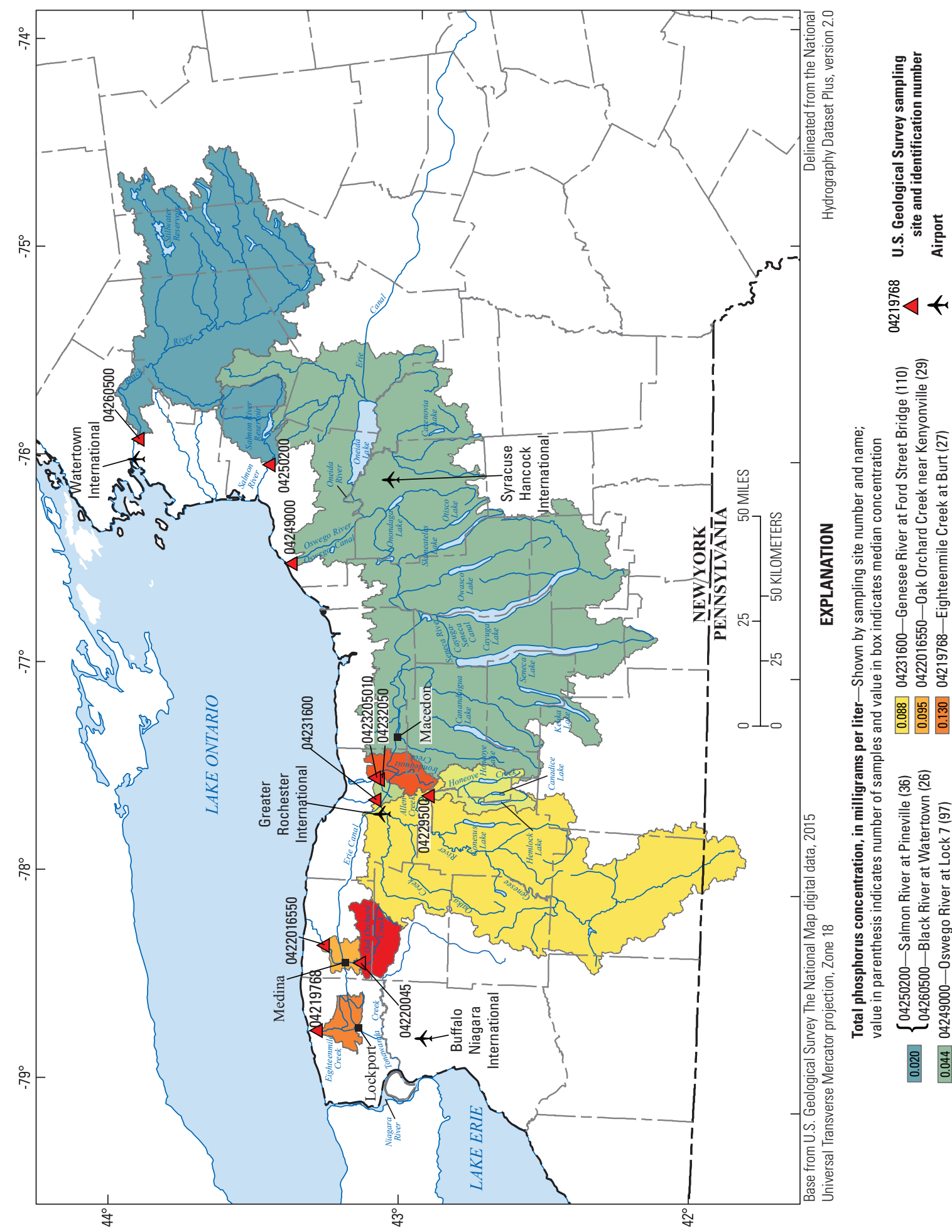

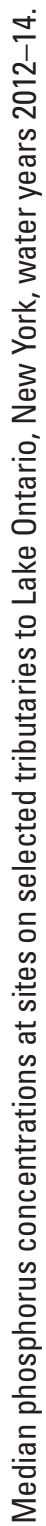



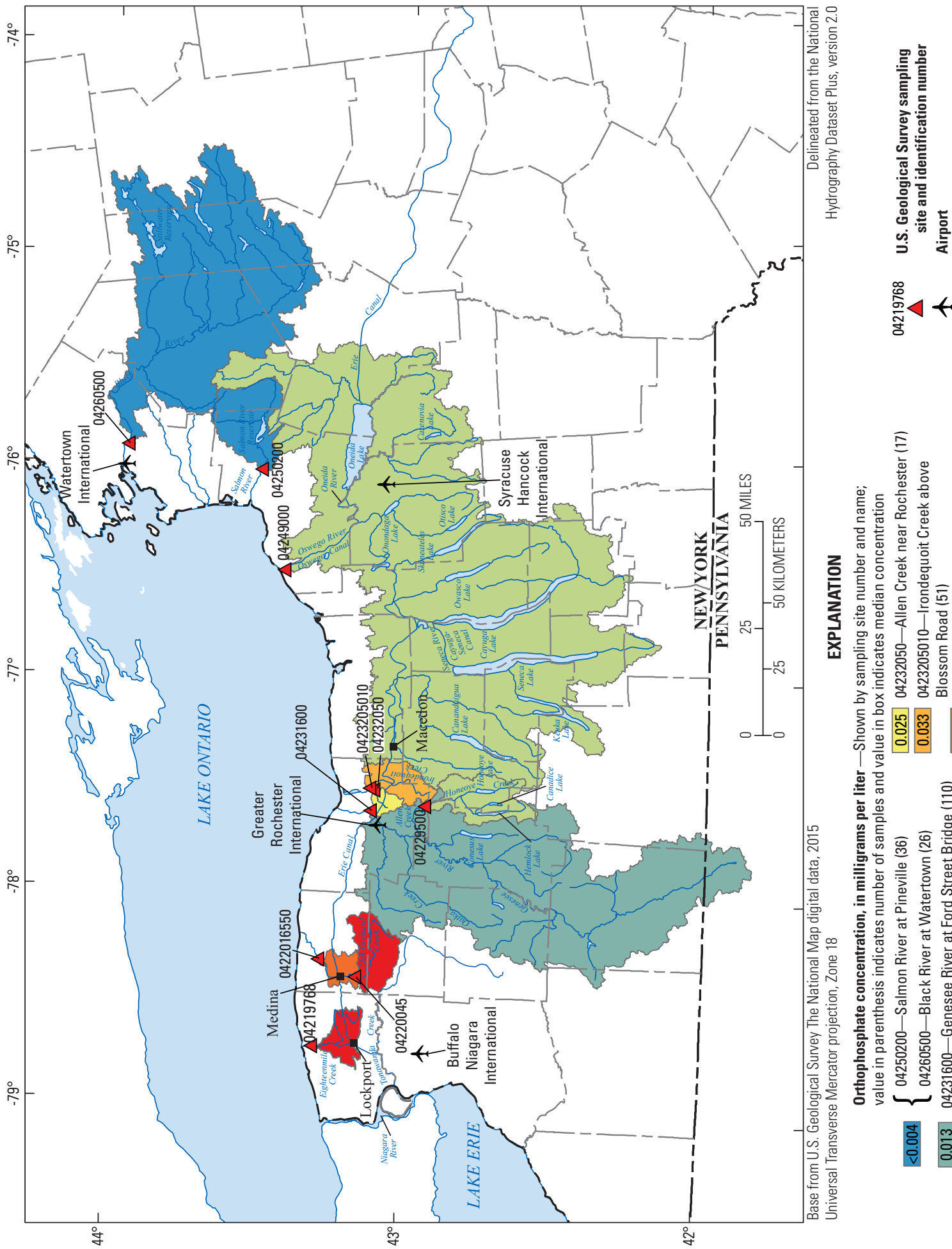

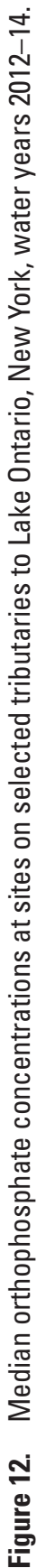



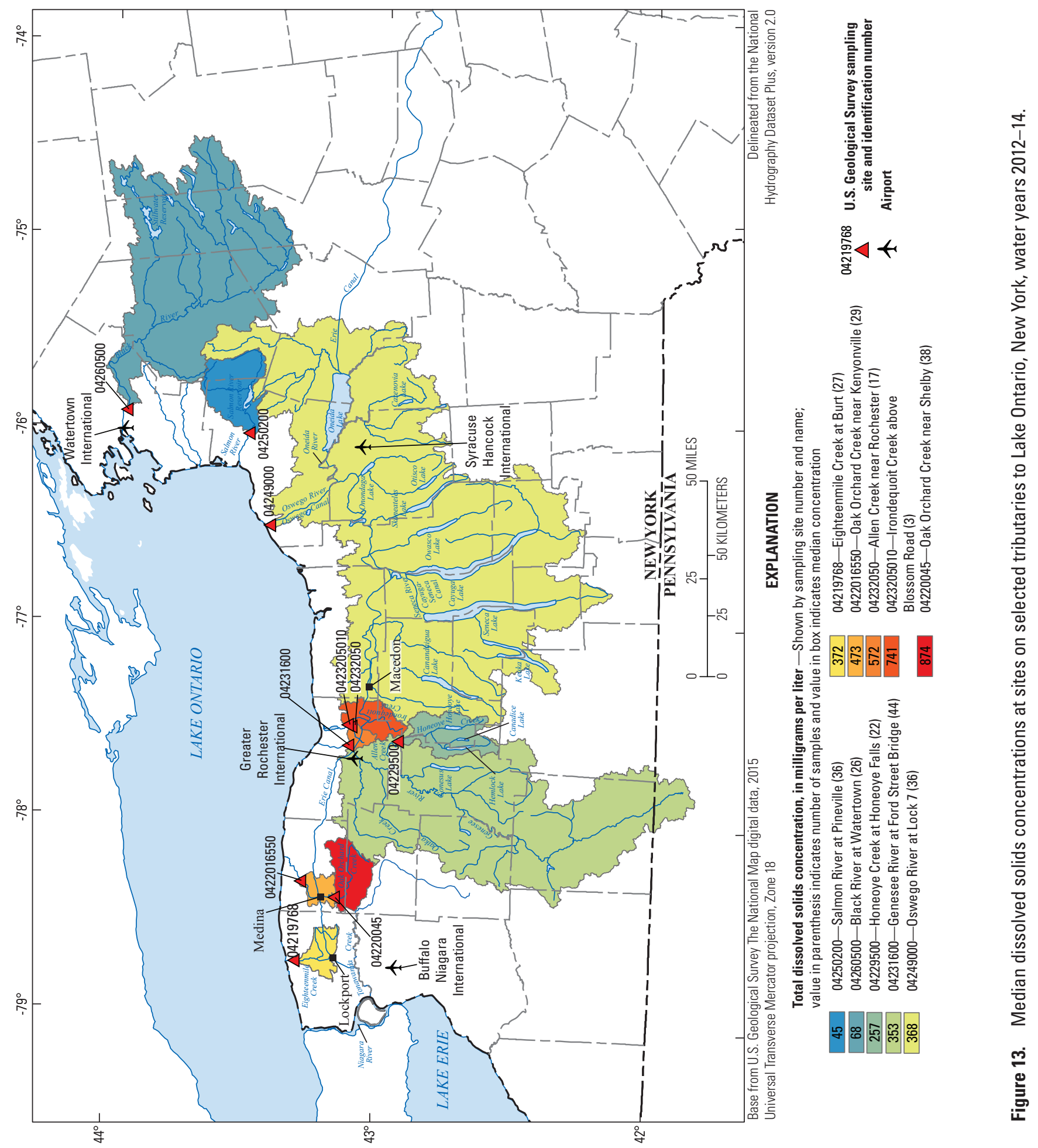
in this study except for total suspended solids. The reduction in nutrient concentrations can be directly attributed to Glenwood Lake north of the village of Medina. Based on comparisons of upstream and downstream Oak Orchard Creek nutrient data, median sample concentrations upstream (near Shelby) are nearly twice as great as those downstream (near Kenyonville). However, maximum concentrations of total suspended solids near Kenyonville far exceed those concentrations at Shelby, and median concentrations of phosphorus, orthophosphate, and total suspended solids near Shelby were 0.185 milligram per liter $(\mathrm{mg} / \mathrm{L}), 0.079 \mathrm{mg} / \mathrm{L}$, and $874 \mathrm{mg} / \mathrm{L}$, respectively, and near Kenyonville were $0.095 \mathrm{mg} / \mathrm{L}, 0.048 \mathrm{mg} / \mathrm{L}$, and $473 \mathrm{mg} / \mathrm{L}$, respectively. A wastewater treatment plant contributes discharges into Glenwood Lake from the village of Medina; however, any measure of phosphorus effects is removed at Glenwood Lake by the time flows reach Kenyonville. Other possible contributions of high suspended solids found downstream can be measured during localized storm events, and although the median annual concentration is less at Kenyonville than at Shelby, a greater percentage of erodible soils are in agricultural areas to the northeast of Medina, and these contributions have not been measured during higher end runoff events.

Eighteenmile Creek at Burt had the third highest median annual phosphorus concentration $(0.130 \mathrm{mg} / \mathrm{L})$ presumably from agricultural runoff and discharge from the city of Lockport wastewater treatment plant. Eighteenmile Creek at Burt had the same median annual concentrations of orthophosphate $(0.079 \mathrm{mg} / \mathrm{L})$ as Oak Orchard Creek near Shelby (fig. 12; table 3). Median concentrations may be slightly less at Eighteenmile Creek than Oak Orchard Creek near Shelby as a result of the highest maximum concentrations $(0.324 \mathrm{mg} / \mathrm{L})$ being measured at Oak Orchard Creek near Shelby and that the Eighteenmile Creek constituent concentrations are not available for water year 2014, affecting the overall medians for comparison. Median annual concentrations of dissolved solids $(372 \mathrm{mg} / \mathrm{L})$ are primarily attributed to year-round groundwater discharges from mineralized bedrock and seasonal contributions from salt applications used for road deicing.

In the Genesee River, median annual concentration of total suspended solids $(31 \mathrm{mg} / \mathrm{L})$ was the second highest measured in the study and phosphorus $(0.088 \mathrm{mg} / \mathrm{L})$ was among the highest measured. Of the 10 monitored sites, the maximum concentrations of total suspended solids and phosphorus of $1,220 \mathrm{mg} / \mathrm{L}$ and $0.998 \mathrm{mg} / \mathrm{L}$, respectively (figs. 10 and 11; table 3) were measured in this tributary. The high phosphorus concentrations in the Genesee River presumably reflect solidphase transport associated with the large suspended sediment loads that are derived from agricultural areas in the basin and from streambank erosion (New York State Department of Environmental Conservation, 2003). Although not always correlated directly with total suspended solids concentrations, particulate phosphorus concentrations are often correlated to sediment concentrations. Honeoye Creek discharges into the Genesee River and reflects some of the same solid-phase transport conditions for suspended solids (median annual concentration $25 \mathrm{mg} / \mathrm{L}$ ) as seen in the Genesee River Basin.

The median concentrations of phosphorus and orthophosphate at Honeoye Creek at Honeoye Falls were found to have similar results; however, $69 \mathrm{mi}^{2}$ is not within the measured drainage area downstream from the gage site and is thus excluded. Extensive agricultural land use likely contributes to high concentrations of phosphorus and orthophosphate for the entire Honeoye Creek watershed.

Irondequoit Creek and Allen Creek have well-documented high chloride concentrations (Sherwood, 2005; Hayhurst and others, 2010), which are reflected in the dissolved solids concentrations (fig. 13; table 3); these locations have the second and third highest median dissolved solids concentrations ( $741 \mathrm{mg} / \mathrm{L}$ and $572 \mathrm{mg} / \mathrm{L}$, respectively) of the study sites. The salt application rates are generally higher in these two basins because both basins comprise mostly urban land use with dense population and road networks (Sherwood, 2005). Of all the monitored tributaries, Irondequoit Creek near Rochester has the highest median annual suspended solids concentration $(96 \mathrm{mg} / \mathrm{L})$ and the second highest median annual phosphorus concentration $(0.175 \mathrm{mg} / \mathrm{L})$.

Concentrations of nutrients and solids were lowest at the Oswego River at Oswego, the Salmon River at Pineville, and the Black River at Watertown sites. The Oswego River Basin has a large amount of agricultural land, but one factor that may reduce sediment and particulate phosphorus concentrations are the seven Finger Lakes and Oneida Lake that tend to be sediment retention areas for much of the basin. Each Finger Lake has a control structure at its northern end that regulates the water discharged to the Seneca and Oneida Rivers, the major tributaries to the Oswego River. In addition the entire flow of the Oswego River watershed is regulated as part of the New York State Barge Canal system. The Salmon and Black Rivers contribute large volumes of water to eastern Lake Ontario and have very low concentrations of all constituents in this study. The land cover is dominated by forest, with limited urbanization, and these rivers receive substantial and sustained base flow.

\section{Constituent Loads}

Load calculations provide an estimate of the amount of a given constituent that moves in streamflow past an observed point providing a result as a mass per unit of time. Knowledge of loads of chemical constituents is important in evaluating transport processes and assessing the effectiveness of best management practices that are implemented to control nonpoint sources of these constituents.

In this study, the USGS R Load Estimation (rloadest) package (Lorenz and others, 2015) was used to estimate daily mean constituent concentrations and loads through a log-linear regression model that uses streamflow, time, and seasonal indicators (cyclic sine and cosine functions of time) as explanatory variables (Helsel and Hirsch, 2002; Runkel and others, 
2004). The package can handle censored concentrations (those concentrations that are below an analytical detection limit) through an adjusted maximum likelihood estimation routine. Regression coefficients and associated $t$-statistics for each explanatory variable are calculated, and daily loads are computed from the estimated daily mean constituent concentrations and measured daily mean flows. The daily loads are summed to compute monthly and annual totals. The summary statistics and the bias diagnostics in the rloadest package compare observed and estimated loads for all dates on which samples were collected during the study period. The diagnostic parameters include load bias $(B p)$, which indicates whether the regression equation overestimates or underestimates the estimated loads. If the $B p$ value was greater than plus-orminus 25 percent, then the model was not to be used (Lorenz, 2013). The $B p$ statistic can be inaccurate if there are too few observed values or too many censored values to create the load regression equation. In this report, the model variables were retained only when the $p$-value for a given regression coefficient was less than 0.05 , which indicated that the coefficient was statistically significant.

The rloadest package regression coefficients are directly related to basin land cover, to physical changes, and to biological processes of nutrient cycles. For example, increased transport during periods of storm runoff and high streamflow attributed to nonpoint sources (large spread land use) would have positive coefficients indicative of linear dependence of log-transformed concentration on log-transformed streamflow; negative coefficients indicate a dilution effect on point sources. The positive (increasing) and negative (decreasing) and magnitude components of linear time variables indicate the presence and direction of a monotonic trend in a constituent load. The presence of a seasonal trend is determined through the actual regression coefficients for a combined sineplus-cosine Fourier function. Generally, dependence of concentration and loads on variables of flow $\left(Q\right.$ and $\left.Q^{2}\right)$, monotonic time trend $(T)$, and seasonal trend (based on sinusoidal function $[S S]$ ) is measured by the coefficient of determination $\left(R^{2}\right)$, which describes the amount of variance in loads from an explanatory model. Table 4 summarizes the statistically significant model variables, the $B p$, and the $R^{2}$ coefficients for four constituents at the 10 monitored sites. Insufficient data precluded load estimation for certain constituents and (or) years at Eighteenmile Creek, Honeoye Creek, the Genesee River, Allen Creek, Irondequoit Creek, and the Oswego River. Table 4 also summarizes the additional years of data that were added to the data from this study and used to produce a load model for water years 2012-14.

Loads of suspended solids, phosphorus, orthophosphate, and dissolved solids at most monitored sites were estimated using a regression model as described above; however, one site (Irondequoit Creek) had insufficient data, and the regression models developed for two constituents, even after the addition of data from outside the study period, are considered poor (table 4). Suspended solids loads at Irondequoit Creek were estimated using the best-fit model, but the $B p$ indicates that the loads were overestimated by 48.8 percent. Dissolved solids loads at Irondequoit Creek were estimated as the product of the median concentration and natural logarithm $[\ln (Q)]$ for a given year because there were too few samples to produce a significant model. Orthophosphate loads at Salmon River could not be estimated because all concentrations for samples collected were below the analytical detection limit. Suspended solids loads could not be calculated at Eighteenmile Creek and the Oswego, Salmon, and Black Rivers because all concentrations for samples collected were below the analytical detection limit. Detectable concentrations may exist during some hydrologic events, such as the rising limb of a storm hydrograph, but such events were not sampled on these four streams during the study period.

The estimated loads for all constituents at all sites where positively correlated with streamflow, which indicated that loads in these streams were dominated by runoff and nonpoint sources. The larger basins generated larger constituent loads than the smaller basins simply by virtue of their size. Basinto-basin comparisons of constituent loads were possible by normalizing the load data by basin area to derive constituent yields (load per unit area). Annual and mean annual loads and yields of the four constituents are summarized for the 10 study sites in table 5, and mean annual yields are displayed in figures 14 through 17.

Annual yields of total suspended solids (fig. 14; table 5) were greatest from the Genesee River Basin (mean of 184 short tons per square mile $\left[\mathrm{t} / \mathrm{mi}^{2}\right]$, ranging from 98.3 to $307 \mathrm{t} / \mathrm{mi}^{2}$ for water years 2012-14), where agricultural activities in highly erodible soils dominates the land use. The Irondequoit Creek Basin also had relatively large estimated yields of suspended solids (mean of $165 \mathrm{t} / \mathrm{mi}^{2}$, ranging from 105 to $200 \mathrm{t} / \mathrm{mi}^{2}$ ) and in 2012 and 2013 had larger estimated yields than the Genesee River. Compared with yields at the other monitoring sites, Oak Orchard Creek near Shelby had the lowest suspended solid yields (mean of $12.1 \mathrm{t} / \mathrm{mi}^{2}$, ranging from 8.8 to $14.7 \mathrm{t} / \mathrm{mi}^{2}$ ). Oak Orchard Creek near Kenyonville (mean of $42.2 \mathrm{t} / \mathrm{mi}^{2}$, ranging from 33.7 to $50.6 \mathrm{t} / \mathrm{mi}^{2}$ ) had yields larger than Allen Creek (mean of $30.9 \mathrm{t} / \mathrm{mi}^{2}$, ranging from 24.9 to $42.2 \mathrm{t} / \mathrm{mi}^{2}$ ). The results for the Oak Orchard Creek Basin indicated that suspended solid loads were lower from the upper basin (near Shelby) - presumably due to the sedimentation process that is facilitated by the large wetland area in this part of the basin - than from the lower basin (near Kenyonville) which has a larger area of agricultural land use. The yields of the Eighteenmile Creek, Oswego River, Salmon River, and Black River Basins displayed in figure 14 are not considered representative of annual yields because the sampling protocol was inadequate to cover large storm events.

Phosphorus yields (fig. 15; table 5) in the Eighteenmile Creek Basin were similar to those at Oak Orchard Creek near Kenyonville, presumably as a result of the discharge from the Burt wastewater treatment plant and agricultural land use. The New York State Barge Canal may be another source of nutrients to Eighteenmile Creek at the city of Lockport where excess canal water can overflow into Eighteenmile Creek. The 
Table 4. Estimated annual constituent loads at monitoring sites tributary to Lake Ontario, New York, water years 2012-14, and statistically significant model variables.

[Site locations are shown in figure 1. $Q$, flow; $T$, linear time trend; $S S$, sinusoidal functions to account for the effects of seasonality; $n$, number of samples; $B p$, load bias, in percent; $R^{2}$, regression coefficient of determination, in percent; ln, natural logarithm; --, no data]

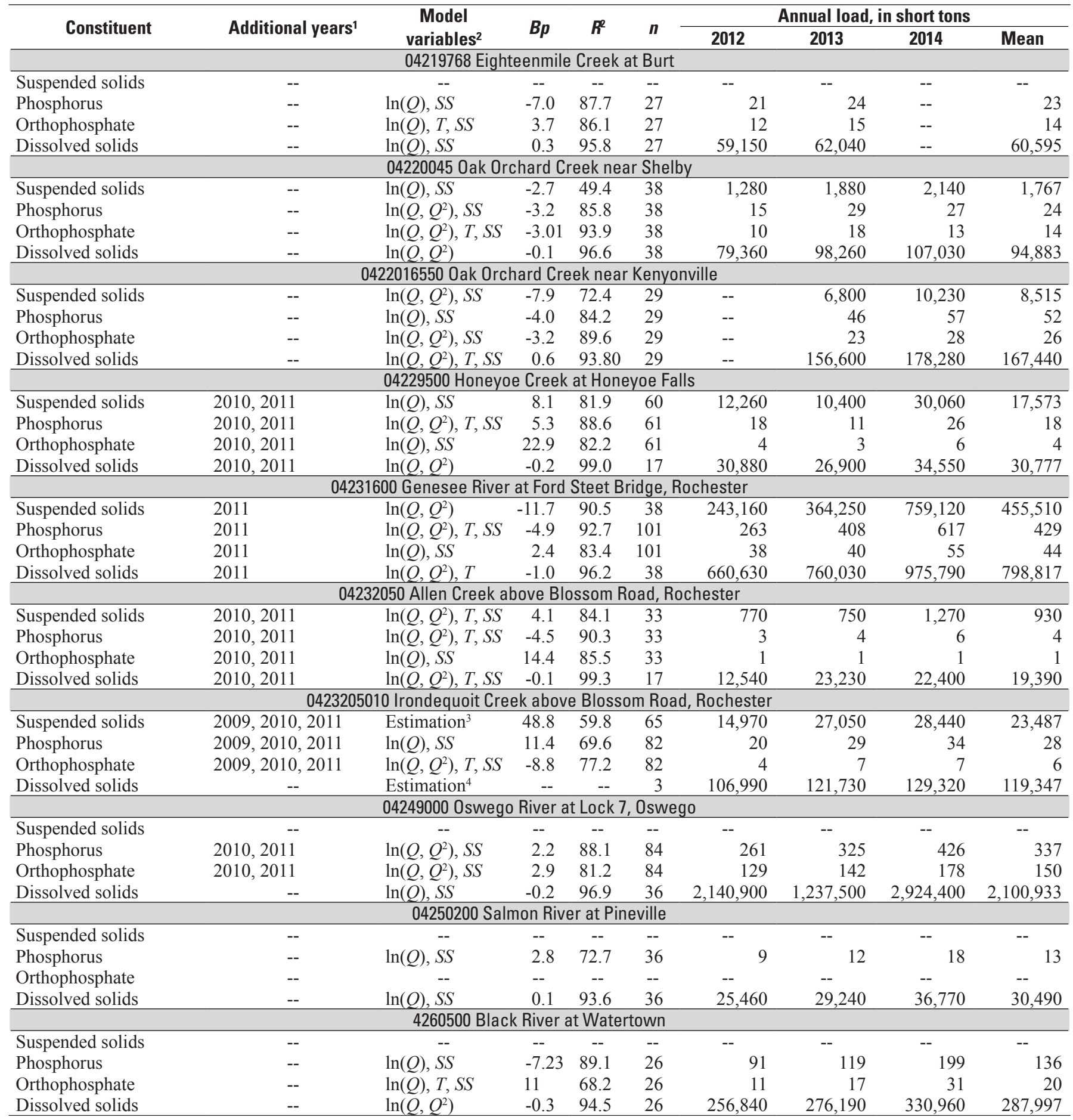

'Insufficient data for estimation using regression model for 2012-14. Load estimated from the product of additional years data found in the U.S. Geological Survey National Water Information System.

${ }^{2}$ Loads estimated using regression model described by Helsel and Hirsch (2002) and Runkel and others (2004), except where noted.

${ }^{3}$ Insufficient data. Load estimated from $\ln (Q), T, S S$ with a $B p$ of greater than 25 percent, indicating overestimation.

${ }^{4}$ Insufficient data. Load estimated from the product of $\ln (Q)$, annual mean flow for a given year, and median constiuent concntrations (2012-14). 


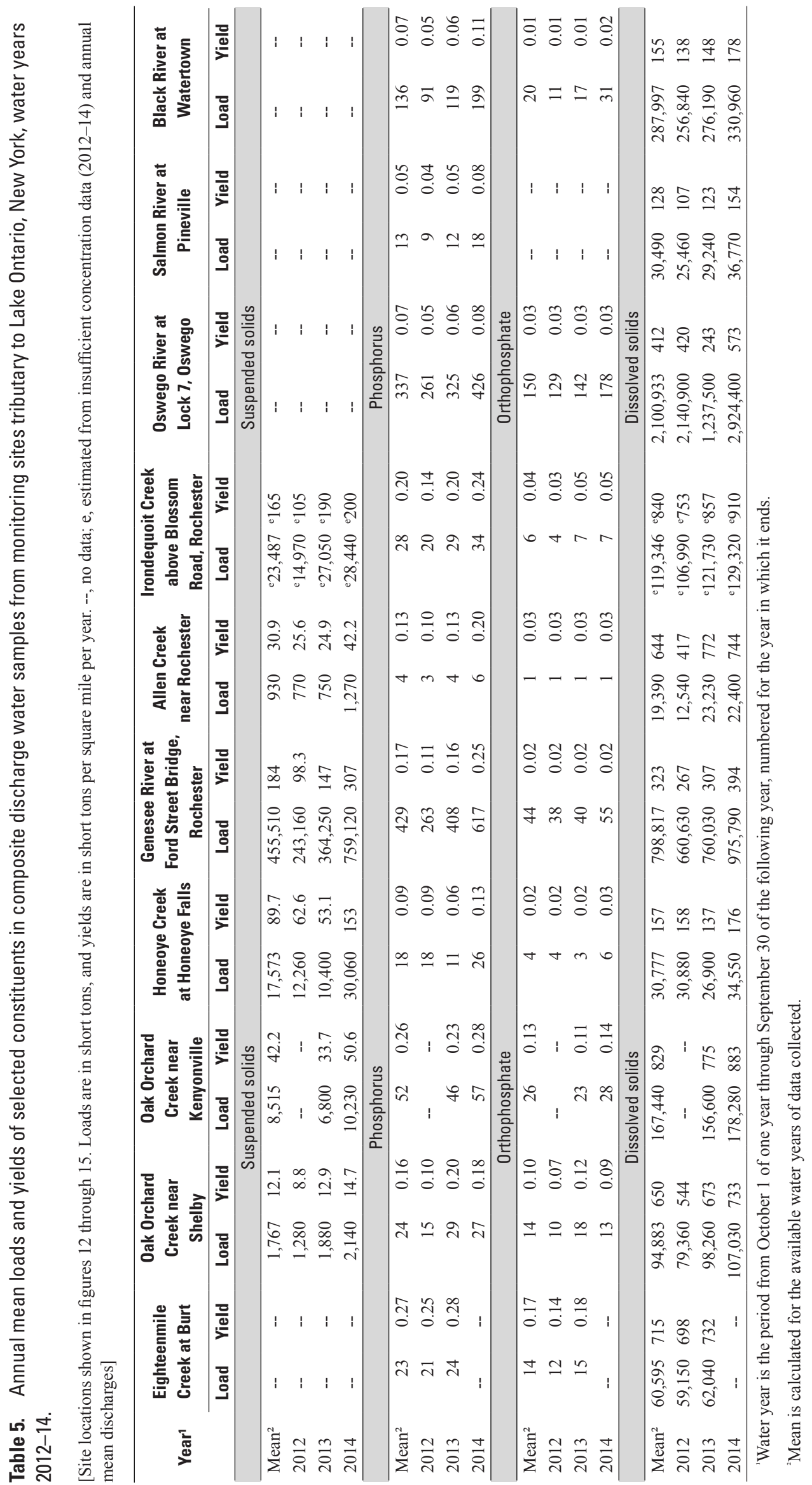




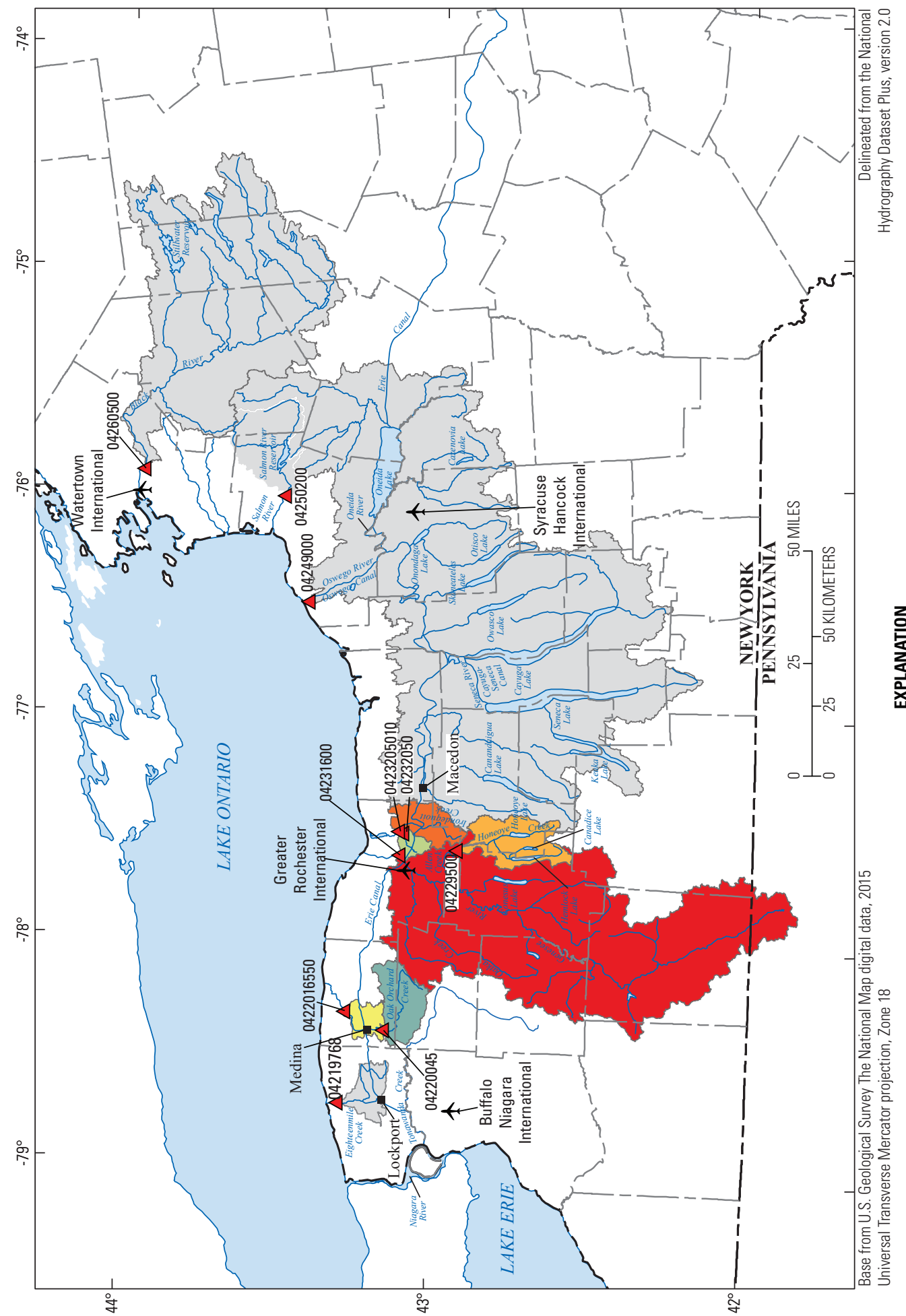

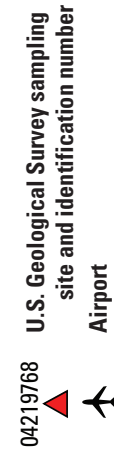

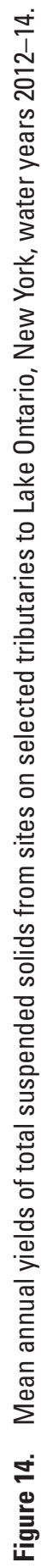



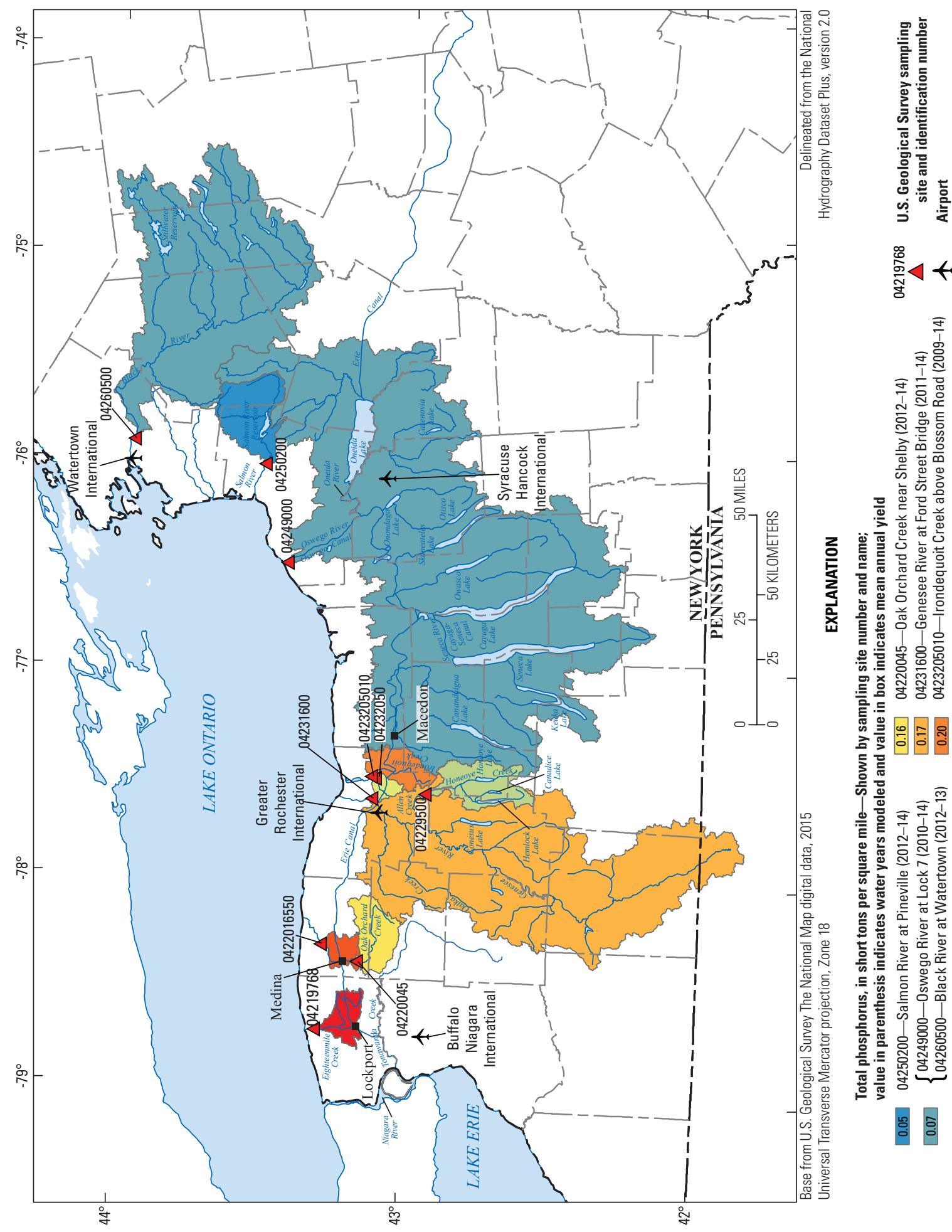

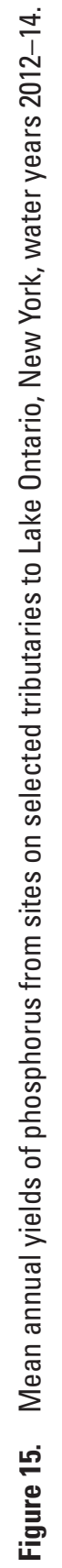



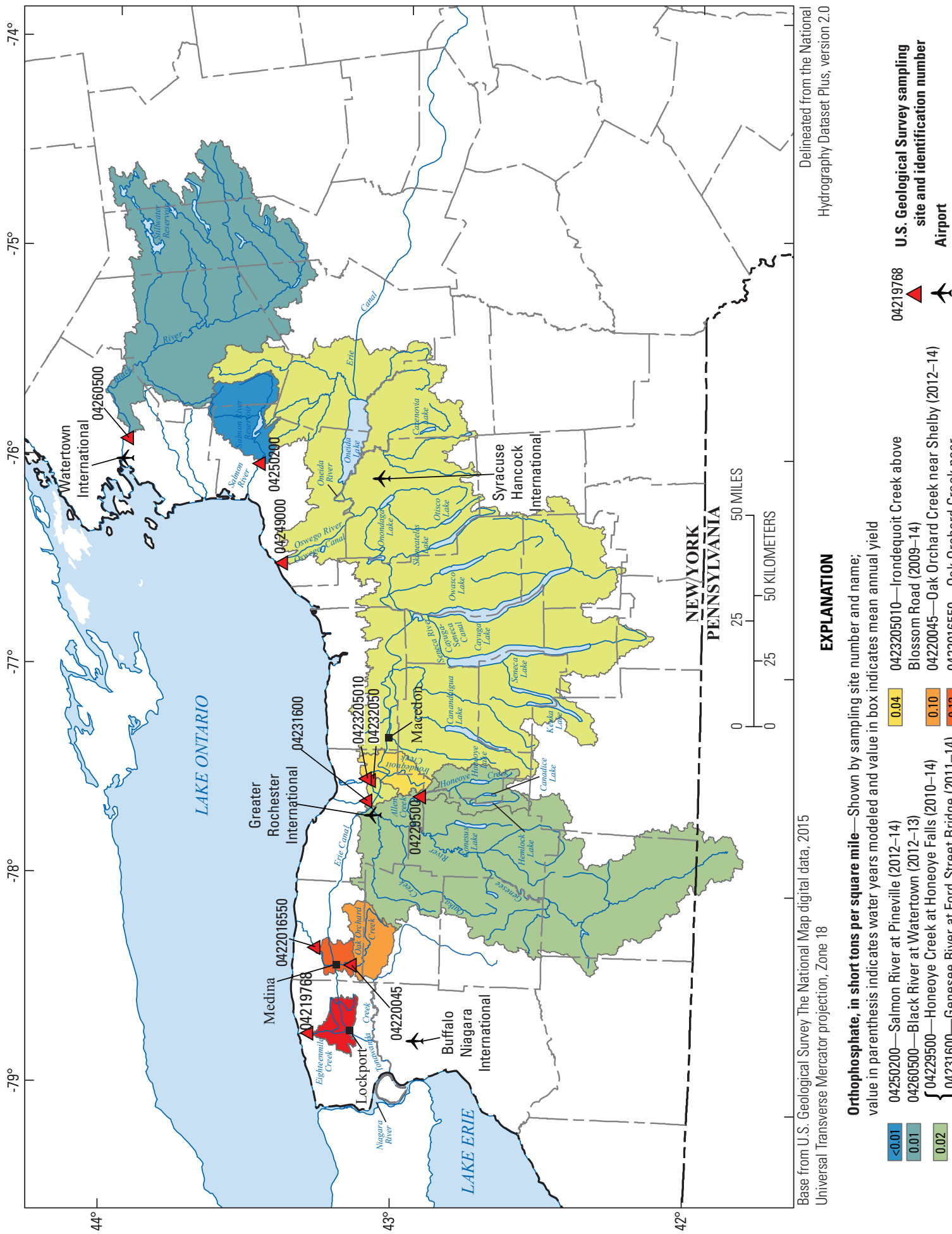

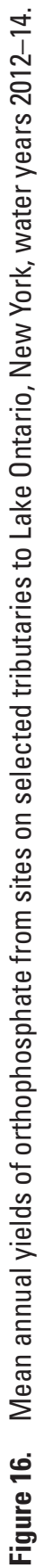




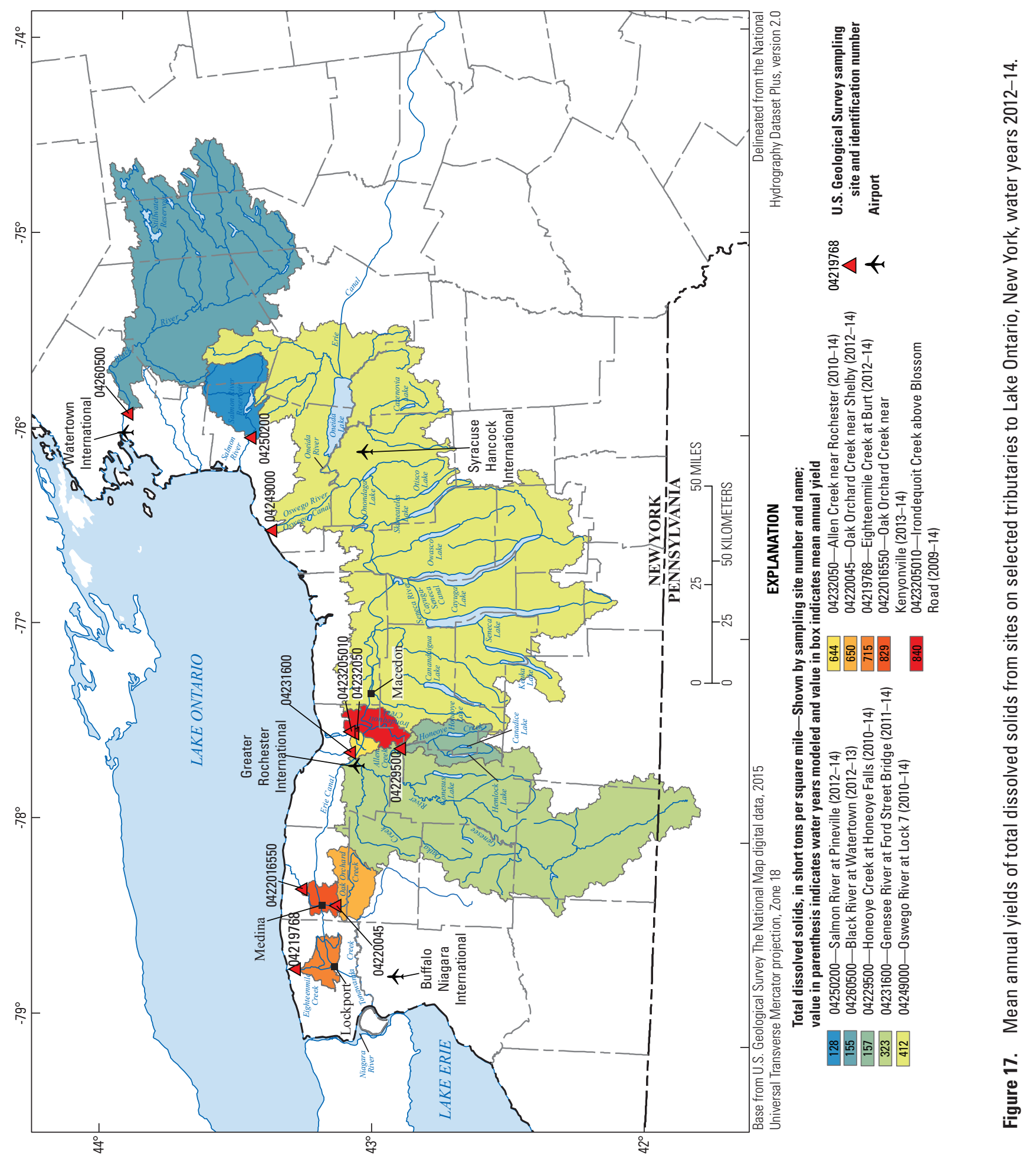


yields at the Eighteenmile Creek Basin (mean of $0.27 \mathrm{t} / \mathrm{mi}^{2}$, ranging from 0.25 to $0.28 \mathrm{t} / \mathrm{mi}^{2}$ ) are comparable to yields in the lower Oak Orchard Creek Basin near Kenyonville (mean of $0.26 \mathrm{t} / \mathrm{mi}^{2}$, ranging from 0.23 to $0.28 \mathrm{t} / \mathrm{mi}^{2}$ ), most likely attributed to discharge from the Medina wastewater treatment plant and agricultural land use. The Irondequoit Creek and Genesee River Basins also had considerable sources of phosphorus that are reflected in high yields in figure 15. The relatively high yields of phosphorus for the Genesee River Basin are associated with suspended sediment generated from agricultural areas and streambank erosion (New York State Department of Environmental Conservation, 2003). In contrast, the Oswego River, Salmon River, and Black River Basins have greater streamflow yields (fig. 7) than the other basins but have smaller mean phosphorus yields of $0.07 \mathrm{t} /$ $\mathrm{mi}^{2}, 0.05 \mathrm{t} / \mathrm{mi}^{2}$, and $0.07 \mathrm{t} / \mathrm{mi}^{2}$, respectively. These low yields are attributed to the large percentages of forested land in these basins.

In this study, the Irondequoit Creek Basin was the third greatest contributor of phosphorus yields (mean of $0.20 \mathrm{t} /$ $\mathrm{mi}^{2}$, ranging from 0.14 to $0.24 \mathrm{t} / \mathrm{mi}^{2}$ ) and the fourth greatest contributor of orthophosphate yields (mean of $0.04 \mathrm{t} / \mathrm{mi}^{2}$, ranging from 0.03 to $0.05 \mathrm{t} / \mathrm{mi}^{2}$ ). However, the natural mitigation effects of the Ellison Park wetlands on phosphorus and orthophosphate loads, which would otherwise be transported to Irondequoit Bay and Lake Ontario, would suggest an increase of orthophosphate yields and decrease phosphorus loads and have been documented by Coon $(1997,2004)$ and Coon and others (2000).

Orthophosphate yields from the upper Oak Orchard Creek Basin at Shelby (mean of $0.10 \mathrm{t} / \mathrm{mi}^{2}$, ranging from 0.07 to $0.12 \mathrm{t} / \mathrm{mi}^{2}$ ) were slightly elevated presumably due to export from wetlands and agricultural land. The yields were similar or slightly higher downstream at Oak Orchard Creek near Kenyonville (mean of $0.13 \mathrm{t} / \mathrm{mi}^{2}$, ranging from 0.11 to $0.14 \mathrm{t} /$ $\mathrm{mi}^{2}$; fig. 16; table 5). The largest orthophosphate yield across all basins occurred at Eighteenmile Creek (mean of $0.17 \mathrm{t} / \mathrm{mi}^{2}$, ranging from 0.14 to $0.18 \mathrm{t} / \mathrm{mi}^{2}$ ), which may be derived from fertilizer and manure applied to agricultural land, from runoff from urban areas and wastewater treatment plants, and from the New York State Barge Canal. Yields of orthophosphate at 9 of the 10 basins are shown in figure 16 with a small profusion in areas with larger streamflow yields.

Annual yields of dissolved solids are usually greatest in urbanized basins where atmospheric deposition and large applications of road-deicing salt on impervious surfaces can increase dissolved solid loads. The Irondequoit Creek Basin had the largest annual estimated yield of dissolved solids (mean of $840 \mathrm{t} / \mathrm{mi}^{2}$, ranging from 753 to $910 \mathrm{t} / \mathrm{mi}^{2}$ ), which is attributed to road-deicing salts from urban areas. The Oak Orchard Creek near Kenyonville and Eighteenmile Creek Basins follow with similar mean annual yields of $829 \mathrm{t} / \mathrm{mi}^{2}$ and $715 \mathrm{t} / \mathrm{mi}^{2}$, respectively (fig. 17; table 5). Because dissolved solids can be contributed from groundwater in the all basins of this study, a relative assumption of groundwater yields can be made with base flow contributions. The areas with large yields of dissolved solids that are not urbanized may have large discharges from dissolved minerals in groundwater as seen at both Eighteenmile Creek and Oak Orchard Creek Basins (Kappel and Jennings, 2012)

\section{Summary}

This report presents interpretations of flow and waterquality data at 10 monitoring sites for the periods from October 2011 through September 2014. The total measured watershed for tributaries in New York draining to Lake Ontario is 10,105 square miles $\left(\mathrm{mi}^{2}\right)$ of mixed land uses (agriculture and developed) and land covers (open water, barren, forest, and wetlands).

Precipitation and air temperature were measured at four airports where weather stations are operated and maintained by the National Weather Service. Average annual precipitation was the highest at Buffalo Niagara International Airport and was the lowest at Greater Rochester International Airport for the 3-year period of the study. Precipitation amounts at Syracuse Hancock International and Watertown International Airports were relatively similar for the period. Air temperatures across the southern parts of Lake Ontario were similar at Buffalo Niagara International, Greater Rochester International, and Syracuse Hancock International Airports; however, seasonal temperatures at Watertown International Airport are colder in the winter and significantly cooler during the summer months. Some noticeable variability exists in precipitation and air temperature data from September 2011 through September 2014 compared with the 30-year monthly normal, specifically during the late winter and early spring of 2012.

Streamflow and water-quality sites were monitored by the U.S. Geological Survey. The smallest basin, Allen Creek, has the second lowest streamflow yield (flow per unit area), and the Honeoye Creek Basin has the lowest streamflow yield overall. Honeoye Creek streamflow yield reflects a decrease in flows because of year-round withdrawals from Hemlock Lake and Canadice Lake for the water supply of the City of Rochester. The Salmon and Black Rivers had the highest streamflow yields because of sustained year-round discharge from the Tug Hill aquifer. The Eighteenmile Creek and Oak Orchard Creek Basins had relatively high streamflow yields due in part to groundwater influences from the Niagara Escarpment and seasonal overflow discharges from the New York State Barge Canal.

Water samples from the 10 monitoring sites were analyzed for orthophosphate, phosphorus, total dissolved solids, and total suspended solids. The loads of constituents were computed from concentration data and the daily flows recorded for each monitoring site (where concentration and daily flow data were available). Statistical evaluations of the loads indicated that all constituents at all sites were positively correlated with streamflow. Multiple sites had insufficient data, and additional data from years prior to the study 
period were compiled to permit estimations of loads with regression models.

Annual constituent yields (loads per unit area) were computed to assess the relative contributions and warrant direct comparison of loads among the monitored basins. All sites that have high total suspended solids were attributed to agricultural land use in highly erodible soils and included the Genesee River, Irondequoit Creek, and Honeoye Creek Basins. These basins contribute the highest concentrations and largest mean yields (184 short tons per square mile $\left[\mathrm{t} / \mathrm{mi}^{2}\right], 165 \mathrm{t} / \mathrm{mi}^{2}$, and $89.7 \mathrm{t} / \mathrm{mi}^{2}$, respectively) to Lake Ontario. Suspended solids concentrations at four monitored tributaries (Eighteenmile Creek, Oswego River, Salmon River, and Black River) were below the analytical detection limit for all samples collected for the period of the study; therefore, suspended solids loads could not be computed for these sites.

Samples from Eighteenmile Creek, Oak Orchard Creek near Kenyonville, and Irondequoit Creek have the highest concentrations and largest mean annual yields of phosphorus $\left(0.27 \mathrm{t} / \mathrm{mi}^{2}, 0.26 \mathrm{t} / \mathrm{mi}^{2}\right.$, and $0.20 \mathrm{t} / \mathrm{mi}^{2}$, respectively) and orthophosphate $\left(0.17 \mathrm{t} / \mathrm{mi}^{2}, 0.13 \mathrm{t} / \mathrm{mi}^{2}\right.$, and $0.04 \mathrm{t} / \mathrm{mi}^{2}$, respectively). These are the result of a combination of sources, including discharges from wastewater treatment plants, diversions from New York State Barge Canal, and manure and fertilizers applied to agricultural land-use areas. The Salmon and Black Rivers, which drain a substantial amount of forested land cover and have a large groundwater influence, have the lowest concentrations and yields of phosphorus and orthophosphate for tributaries to Lake Ontario for the period of study of 2012-14. Concentrations and yields of phosphorus are also high in the Genesee River $\left(0.17 \mathrm{t} / \mathrm{mi}^{2}\right)$, which are presumably associated with nutrient and sediment transport from agricultural land use in the basin and streambank erosion.

Mean annual yields of dissolved solids are the highest in urbanized land use areas in the Irondequoit Creek, Oak Orchard Creek, and Eighteenmile Creek Basins where seasonal chloride loads attributed to road-deicing salts contribute to dissolved solids yields $\left(840 \mathrm{t} / \mathrm{mi}^{2}, 829 \mathrm{t} / \mathrm{mi}^{2}\right.$, and $715 \mathrm{t} / \mathrm{mi}^{2}$, respectively). Oak Orchard and Eighteenmile Creeks see significant dissolved solids concentrations and yields as a result of groundwater influence from particular bedrock formations, which can produce large amounts of dissolved solids (minerals) from the dissolution of these rocks, a continual process reflected in base flow samples. Groundwater influences in the Salmon River have very low concentrations of dissolved solids as a result of limited interaction with bedrock on the Tug Hill Plateau and the sand and gravel from the Tug Hill aquifer from which the groundwater flows to sustain streamflow in these eastern Lake Ontario basins.

\section{Selected References}

Bloomfield, J.A., ed., 1978, Ecology of the Finger Lakes, v. I of Lakes of New York State: New York, N.Y., Academic Press, $499 \mathrm{p}$.

Cadwell, D.H., 1999, Surficial geologic map of New York: New York State Museum Map and Chart Series no. 40, scale 1:250,000.

Coon, W.F., 1997, Hydrology, sedimentology, and biology of Ellison Park wetland at the mouth of Irondequoit Creek near Rochester, New York: U.S. Geological Survey WaterResources Investigations Report 96-4269, 41 p. [Also available at http://pubs.er.usgs.gov/publication/wri964269.]

Coon, W.F., 2004, Effects of flow modification on a cattail wetland at mouth of Irondequoit Creek near Rochester, New York-Water levels, wetland biota, sediment, and water quality: U.S. Geological Survey Water-Resources Investigations Report 03-4224, 90 p. [Also available at http://pubs.er.usgs.gov/publication/wri034224.]

Coon, W.F., Bernard, J.M, and Seischab, F.K., 2000, Effects of a cattail wetland on water quality of Irondequoit Creek near Rochester, New York: U.S. Geological Survey WaterResources Investigations Report 00-4032, 74 p. [Also available at http://pubs.er.usgs.gov/publication/wri004032.]

Dewald, Tommy, McKay, Lucinda, Bondelid, Timothy, Johnston, Craig, Moore, Richard, and Rea, Alan, 2012, NHDPlus version 2-User guide: U.S. Environmental Protection Agency and U.S. Geological Survey, 181 p., accessed November 15, 2014, at http://www.horizon-systems.com/ NHDPlus/NHDPlusV2_documentation.php.

Fisher, D.W., Isachsen, Y.W., and Rickard, L.V., 1970, Geologic map of New York State: New York State Museum Map and Chart Series no. 15, scale 1:250,000.

Great Lakes Interagency Task Force, 2014, Great Lakes restoration initiative action plan II: Great Lakes Interagency Task Force, 29 p., accessed September 30, 2014, at https://www.glri.us//actionplan/pdfs/glri-action-plan-2.pdf.

Great Lakes Interagency Task Force, [undated], GLRI projects: Great Lakes Interagency Task Force Web site, accessed September 30, 2014, at http:/glri.us/projects/index.html. 
Hayhurst, B.A., Coon, W.F., and Eckhardt, D.A., 2010, Water resources of Monroe County, New York, water years 2003-08-Streamflow, constituent loads, and trends in water quality: U.S. Geological Survey Scientific Investigations Report 2010-5216, 34 p. [Also available at https://pubs.er.usgs.gov/publication/sir20105216.]

Heisig, P.M., 2000, Effects of residential and agricultural land use on the chemical quality of base flow of small streams in the Croton watershed, southeastern New York: U.S. Geological Survey Scientific Investigations Report 99-4173, 16 p. [Also available at https://pubs.er.usgs.gov/publication/ wri994173.]

Helsel, D.R., and Hirsch, R.M., 2002, Statistical methods in water resources: U.S. Geological Survey Techniques of Water-Resources Investigations, book 4, chap. A3, 522 p., accessed July 25, 2010, at https://pubs.er.usgs.gov/ publication/twri04A3.

Homer, C.G., Dewitz, J.A., Yang, Limin, Jin, Suming, Danielson, Patrick, Xian, George, Coulston, John, Herold, N.D., Wickham, J.D., and Megown, Kevin, 2015, Completion of the 2011 national land cover database for the conterminous United States-Representing a decade of land cover change information: Photogrammetric Engineering and Remote Sensing, v. 81, no. 5, p. 345-354.

Kappel, W.M, and Jennings, M.B., 2012, Water resources of the Iroquois National Wildlife Refuge, Genesee and Orleans Counties, New York 2008-2010: U.S. Geological Survey Scientific Investigations Report 2012-5027, 53 p. [Also available at https://pubs.er.usgs.gov/publication/ sir20125027.]

Levesque, V.A., and Oberg, K.A., 2012, Computing discharge using the index velocity method: U.S. Geological Survey Techniques and Methods, book 3, chap. A23, 148 p. [Also available at https://pubs.er.usgs.gov/publication/tm3A23.]

Lorenz, David, 2013, Analysis of an uncensored constituent using a predefined model: U.S. Geological Survey software, accessed December 14, 2015, at https://github.com/ USGS-R/rloadest.

Lorenz, David, Runkel, Rob, De Cicco, Laura, 2015, River load estimation, rloadest package: U.S. Geological Survey software, accessed February 27, 2015, at https://github.com/ USGS-R/rloadest.

Mueller, D.S., Wagner, C.R., Rehmel, M.S., Oberg, K.A., and Rainville, Francois, 2013, Measuring discharge with acoustic Doppler current profilers from a moving boat (ver. 2.0, December 2013): U.S. Geological Survey Techniques and Methods, book 3, chap. A22, 95 p. [Also available at http://dx.doi.org/10.3133/tm3A22.]
New York State Department of Environmental Conservation, 2003, The 2001 Genesee River Basin waterbody inventory and priority waterbodies list: New York State Department of Environmental Conservation, [variously paged], accessed March 11, 2015, at http://www.dec.ny.gov/docs/water_pdf/ pwlgenes03.pdf.

Northeast Regional Climate Center, 2015, CLIMOD field test version: Cornell University Northeast Regional Climate Center database, accessed February 25, 2015, at http://climod2.nrcc.cornell.edu/.

Randall, A.D., 1996, Mean annual runoff, precipitation, and evapotranspiration in the glaciated northeastern United States, 1951-80: U.S. Geological Survey Open-File Report 96-395, 2 pls. [Also available at http://pubs.er.usgs.gov/ publication/ofr96395.]

Rantz, S.E., and others, 1982, Measurement and computation of streamflow-Volumes 1 and 2: U.S. Geological Survey Water-Supply Paper 2175, 631 p. [Also available at http://pubs.usgs.gov/wsp/wsp2175/.]

Runkel, R.L., Crawford, C.G., and Cohn, T.A., 2004, Load estimator (LOADEST) - A FORTRAN program for estimating constituent loads in streams and rivers: U.S. Geological Survey Techniques and Methods, book 4, chap. A5, 69 p. [Also available at https://pubs.er.usgs.gov/publication/ tm4A5.]

Sauer, V.B., and Turnipseed, D.P., 2010, Stage measurement at gaging stations: U.S. Geological Survey Techniques and Methods, book 3, chap. A7, 45 p. [Also available at https://pubs.er.usgs.gov/publication/tm3A7.]

Sherwood, D.A., 2005, Water resources of Monroe County, New York, water years 200002 - Atmospheric deposition, ground water, streamflow, trends in water quality, and chemical loads in streams: U.S. Geological Survey Scientific Investigations Report 2005-5107, 55 p. [Also available at http://pubs.er.usgs.gov/publication/sir20055107.]

Turnipseed, D.P., and Sauer, V.B., 2010, Discharge measurements at gaging stations: U.S. Geological Survey Techniques and Methods, book 3, chap. A8, 87 p. (Also available at https://pubs.er.usgs.gov/publication/tm3A8.)

U.S. Department of Agriculture, Natural Resources Conservation Service, 2015, Geospatial data gateway: U.S. Department of Agriculture, Natural Resources Conservation Service database, accessed March 10, 2015, at http://datagateway.nrcs.usda.gov/.

U.S. Geological Survey, 2014a, The national field manual for the collection of water-quality data (version 2.2): U.S. Geological Survey Techniques and Methods, book 9 , chaps. A1-A9, [variously paged], accessed January 5, 2015, at http://water.usgs.gov/owq/FieldManual/.

U.S. Geological Survey, 2014b, USGS water data for the nation: U.S. Geological Survey National Water Information System database, accessed December 22, 2014, at http://waterdata.usgs.gov/nwis/. 


\section{Appendixes}

[Available for download at http://dx.doi.org/10.3133/sir20165084]

Appendix 1. Streamflow and streamflow yields at selected tributaries to Lake Ontario, New York, water years 2012-14.

Appendix 2. Water-quality data at selected tributaries to Lake Ontario, New York, water year 2012-14. 
For additional information write to:

Director, New York Water Science Center U.S. Geological Survey

30 Brown Road

Ithaca, NY 14850

Information requests:

(518) 285-5602

or visit our Web site at: http://ny.water.usgs.gov

Publishing support by:

The Pembroke Publishing Service Center 


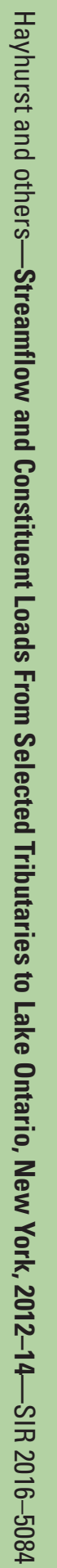

